\title{
Epidemiological differences in the impact of COVID-19 vaccination in the United States and China
}

\author{
Monia Makhoul ${ }^{1,2,3}$, Hiam Chemaitelly ${ }^{1,2}$, Houssein H. Ayoub ${ }^{4}$, Shaheen Seedat ${ }^{1,2,3}$, and Laith J. \\ Abu-Raddad ${ }^{1,2,3^{*}}$
}

${ }^{1}$ Infectious Disease Epidemiology Group, Weill Cornell Medicine-Qatar, Cornell University, Qatar Foundation - Education City, Doha, Qatar

${ }^{2}$ World Health Organization Collaborating Centre for Disease Epidemiology Analytics on HIV/AIDS, Sexually Transmitted Infections, and Viral Hepatitis, Weill Cornell Medicine-Qatar, Cornell University, Qatar Foundation - Education City, Doha, Qatar

${ }^{3}$ Department of Population Health Sciences, Weill Cornell Medicine, Cornell University, New York City, New York, USA

${ }^{4}$ Department of Mathematics, Statistics, and Physics, Qatar University, Doha, Qatar

Word count: Abstract: 223 words, Main Text: 3,041 words.

Number of figures: 5 .

Number of tables: None.

Running head: Epidemiological inequity in vaccine impact.

Disclose funding received for this work: others

\section{*Correspondence:}

Professor Laith J. Abu-Raddad, Infectious Disease Epidemiology Group, Weill Cornell Medicine - Qatar, Qatar Foundation - Education City, P.O. Box 24144, Doha, Qatar. Telephone: +(974) 4492-8321. Fax: +(974) 4492-8333. E-mail: 1ja2002@qatar-med.cornell.edu.

One Sentence Summary: Vaccine impact will be heterogeneous across countries disadvantaging countries at high incidence. This heterogeneity can be alleviated with rapid vaccination scale-up and limited easing of restrictions.

Keywords: SARS-CoV-2, COVID-19, coronavirus, epidemiology, vaccine, mathematical model. 


\begin{abstract}
Background: The objective of this study was to forecast the impact of COVID-19 vaccination in the United States (US) and China, two countries at different epidemic phases.
\end{abstract}

Methods: A mathematical model describing SARS-CoV-2 transmission and disease progression was used to investigate vaccine impact. Impact was assessed both for a vaccine that prevents infection $\left(V E_{S}=95 \%\right)$ and a vaccine that prevents only disease $\left(V E_{P}=95 \%\right)$.

Results: For $V E_{S}=95 \%$ and gradual easing of restrictions, vaccination in the US reduced the peak incidence of infection, disease, and death by $>55 \%$ and cumulative incidence by $>32 \%$, and in China by $>77 \%$ and $>65 \%$, respectively. Nearly three vaccinations were needed to avert one infection in the US, but only one was needed in China. For $V E_{P}=95 \%$, benefits of vaccination were half those for $V E_{S}=95 \%$. In both countries, the impact of vaccination was substantially enhanced with rapid scale-up, vaccine coverage $>50 \%$, and slower or no easing of restrictions, particularly in the US.

Conclusions: COVID-19 vaccination can flatten, delay, and/or prevent future epidemic waves. However, vaccine impact is destined to be heterogeneous across countries because of an underlying "epidemiologic inequity" that reduces benefits for countries already at high incidence, such as the US. Despite $95 \%$ efficacy, actual vaccine impact could be meager in such countries, if vaccine scale-up is slow, acceptance of the vaccine is poor, or restrictions are eased prematurely. 
medRxiv preprint doi: https://doi.org/10.1101/2021.01.07.21249380; this version posted January 8, 2021. The copyright holder for this preprint (which was not certified by peer review) is the author/funder, who has granted medRxiv a license to display the preprint in perpetuity.

All rights reserved. No reuse allowed without permission.

\section{Introduction}

With over 80 million infections and a death toll approaching two million [1], the severe acute respiratory syndrome coronavirus 2 (SARS-CoV-2) pandemic has been one of the most challenging global health emergencies in recent history [2]. The unparalleled burden on healthcare systems has necessitated unprecedented restrictions on mobility and on social and economic activities $[3,4]$. The ensuing losses to national and global economies are probably the largest since the Great Depression $[2,5]$.

We previously developed a mathematical model to investigate the generic population-level impact of SARS-CoV-2 vaccination [6]. In light of recently produced vaccines with $~ 95 \%$ efficacy against Coronavirus Disease 2019 (COVID-19) symptomatic disease [7,8], the model was extended to assess the impact of these novel vaccines on COVID-19 morbidity and mortality in two major countries at different epidemic phases, the United States (US) and China. The impact was assessed under two different assumptions for the mechanism of action of the vaccine, that it prevents both infection and disease, or that it prevents only disease. The impact was further assessed at different levels of vaccine coverage, different time courses for vaccine scaleup, and different schedules for easing of social and physical distancing restrictions, following the launch of vaccination.

\section{Materials and Methods}

\section{Mathematical model and parameterization}

The extended model was age-structured, stratifying the population into cohorts based on vaccination status, age group, infection status, infection stage, and disease stage. Population movement among cohorts was determined using a set of coupled nonlinear differential equations. 
medRxiv preprint doi: https://doi.org/10.1101/2021.01.07.21249380; this version posted January 8, 2021. The copyright holder for this preprint (which was not certified by peer review) is the author/funder, who has granted medRxiv a license to display the preprint in perpetuity.

All rights reserved. No reuse allowed without permission.

Given interest in assessing vaccination impact in the short-term (over only 2021), demography was assumed stable. Contact between individuals in different age groups was determined using an age-mixing matrix that allowed a range of assortativeness in mixing. Details of the model are in Supplementary Information Texts S1A-S1B and Figures S1-S2. The model was coded, fitted, and analyzed using MATLAB R2019a [9].

Since the evidence suggests that reinfection with this virus is a rare event [10-14], those recovered from infection were assumed protected against reinfection, but only for one year, based on the behavior of other "common cold" coronaviruses [15]. For the same purpose, it was assumed that vaccine-induced immunity will also last for only one year. The waning of both natural and vaccine immunity was assumed to follow a gamma distribution of order $n=15$. That is, most people lose their immunity after about one year, and only a small minority lose their immunity after a period that is either much shorter or much longer than one year (Figure S3).

The model was parameterized using state-of-the-art empirical evidence for the infection's natural history and epidemiology. The distribution of infected individuals across the mild (or asymptomatic), severe, or critical infection stages and the infection mortality rate in each age group were based on the analyzed epidemic of France [16]. All age groups were assumed (biologically) equally susceptible to this infection. Population demographic information (size, age distribution, and life expectancy) were obtained from the United Nations World Population Prospects database [17]. Details of model parameters, values, and justifications are in Supplementary Information Text S1C and Tables S1-S2.

\section{Characteristics of the vaccine and scale-up scenarios}

Since the primary endpoint of the vaccine's randomized clinical trials was efficacy of the vaccine against laboratory-confirmed COVID-19 cases $[7,8,18]$, and not just any infection, documented 
medRxiv preprint doi: https://doi.org/10.1101/2021.01.07.21249380; this version posted January 8, 2021. The copyright holder for this preprint (which was not certified by peer review) is the author/funder, who has granted medRxiv a license to display the preprint in perpetuity.

All rights reserved. No reuse allowed without permission.

or undocumented, it is unknown whether the vaccine prophylactically reduces susceptibility to the infection (that is, $V E_{S}$ efficacy defined as the proportional reduction in the susceptibility to infection among those vaccinated, compared to those unvaccinated [6]), or whether it just reduced serious symptomatic COVID-19 cases with no effect on infection (that is, $V E_{P}$ efficacy against disease progression, defined as the proportional reduction in the fraction of individuals with severe or critical infection among those vaccinated, but who still acquired the infection, compared to those unvaccinated [6]). These two mechanisms of action bracket the two extremes for the vaccine's biological effect, with the former mechanism being the most optimistic (reducing both infection and disease) and the latter being the most pessimistic (reducing only disease).

Notwithstanding this uncertainty, the impact of the vaccine was assessed under each of these mechanisms of action, assuming $V E_{S}=95 \%$ or $V E_{P}=95 \%$. In the baseline scenario, the vaccine was introduced in both countries on January 1, 2021 with a scale-up to reach vaccine coverage of $80 \%$ by the end of 2021 . Given that the purpose of vaccination is to alleviate the need for restrictions that have stifled social and economic activities, social distancing restrictions were assumed to be eased gradually over six months, so that "normalcy" would be attained at the end of these six months. Normalcy was defined as a social contact rate in the population equal to that prior to the pandemic.

Since the US has experienced a large epidemic, it was assumed that $20 \%$ of the US population has already been infected by January 1, 2021, with those already infected (if subsequently vaccinated) not benefiting from the immunity conferred by this vaccine. Moreover, the basic reproduction number at time of onset of vaccination was assumed at $R_{0}=1.2$, reflecting the 
medRxiv preprint doi: https://doi.org/10.1101/2021.01.07.21249380; this version posted January 8, 2021. The copyright holder for this preprint (which was not certified by peer review) is the author/funder, who has granted medRxiv a license to display the preprint in perpetuity.

All rights reserved. No reuse allowed without permission.

current phase of an expanding epidemic. It was also assumed that $R_{0}$ will gradually increase with easing of restrictions to reach $R_{0}=4$ at the end of six months. The value of $R_{0}=4$ is justified by existing estimates assuming a "natural" epidemic in the absence of interventions $[19,20]$.

For China, it was assumed that the entire population is still susceptible to the infection, given the small number of documented infections relative to its large population size, and that the epidemic was contained [1,21]. Moreover, it was assumed that $R_{0}=1$ at the onset of vaccination (reflecting the non-expanding epidemic), but that $R_{0}$ will gradually increase with easing of restrictions to reach an $R_{0}=4$ at the end of six months.

\section{Measures of vaccine impact}

The population-level impact of SARS-CoV-2 vaccination was assessed by quantifying incidence, cumulative incidence, and reduction in incidence of infections, severe disease cases, critical disease cases, and COVID-19 deaths arising in the presence of vaccination compared to the counter-factual scenario of no-vaccination. Vaccine effectiveness, that is number of vaccinations needed to avert one infection or one adverse disease outcome (ratio of the number of vaccinations relative to the number of averted outcomes) was further calculated to inform future cost-effectiveness analyses.

\section{Uncertainty analysis}

A multivariable uncertainty analysis was conducted to determine the range of uncertainty for model predictions using five-hundred model runs. At each run, Latin Hypercube sampling $[22,23]$ was applied to select vaccine efficacy from within its reported credible range [8], and to select a vaccine duration of protection within $\pm 30 \%$ of one-year duration. The resulting 
medRxiv preprint doi: https://doi.org/10.1101/2021.01.07.21249380; this version posted January 8, 2021. The copyright holder for this preprint (which was not certified by peer review) is the author/funder, who has granted medRxiv a license to display the preprint in perpetuity.

All rights reserved. No reuse allowed without permission.

distribution for vaccine impact across all 500 runs was used to calculate the predicted means of different outcomes and the uncertainty associated with those means.

\section{Results}

For $V E_{S}=95 \%$, vaccination in the US flattened the epidemic curve, but did not prevent a new epidemic wave, though it resulted in a smaller one, with the assumed gradual easing of restrictions following the onset of vaccination (Figure 1). The vaccine reduced peak incidence of infection, severe disease, critical disease, and COVID-19 death by 59.6\%, 59.5\%, 59.0\%, and $55.3 \%$, respectively, and the cumulative number of infections, severe disease cases, critical disease cases, and deaths by 35.7\%, 35.2\%, 35.0\%, and 32.7\%, respectively, by end of 2021 . However, incidence started to increase toward the end of 2021, as vaccine immunity waned and those previously infected began losing their protective immunity against reinfection.

For $V E_{P}=95 \%$, the vaccination had no impact on infection (as it does not protect against infection) and less impact on disease and death (Figure S4). Peak incidence of severe disease, critical disease, and death was reduced by only $22.0 \%, 22.0 \%$, and $21.1 \%$, respectively. The cumulative number of severe disease cases, critical disease cases, and deaths were reduced by only $17.4 \%, 17.2 \%$, and $16.7 \%$, respectively, by end of 2021 .

In China, the impact of vaccination was larger than in the US, as the vaccine was introduced at a time when disease incidence was negligible. For $V E_{S}=95 \%$, vaccination not only flattened the epidemic curve, but also delayed it by a few months (Figure 2). The vaccine reduced peak incidence of infection, severe disease, critical disease, and death by $85.6 \%, 84.2 \%, 84.3 \%$, and $77.3 \%$, respectively, and the cumulative number of infections, severe disease cases, critical disease cases, and deaths by $65.7 \%, 65.0 \%, 65.3 \%$, and $65.3 \%$, respectively, by end of 2021 . 
medRxiv preprint doi: https://doi.org/10.1101/2021.01.07.21249380; this version posted January 8, 2021. The copyright holder for this preprint (which was not certified by peer review) is the author/funder, who has granted medRxiv a license to display the preprint in perpetuity.

All rights reserved. No reuse allowed without permission.

For $V E_{P}=95 \%$, the vaccination had less impact on disease and death (Figure S5). Peak

incidence of severe disease, critical disease, and death was reduced by $44.5 \%$ for all of these indicators, as well as for their cumulative numbers.

In the US, for $V E_{S}=95 \%$, the cumulative number of averted disease cases increased steadily in response to shorter scale-up (to $80 \%$ coverage) (Figure 3A). However, in China, there was no additional benefit to be had by shortening scale-up to less than 8 months, as the epidemic was fully contained (Figure 3C). Similar results were obtained for $V E_{P}=95 \%$, as shown for the US and China (Figures S6A and S6C), respectively.

For $V E_{S}=95 \%$, the cumulative number of averted disease cases increased steadily with higher vaccine coverage (by end of 2021) in both countries (Figures 3B and 3D). The gains in averted disease cases increased sharply as vaccine coverage exceeded $70 \%$ in the US and $50 \%$ in China, because such coverage prevented a much larger epidemic wave. Similar results were obtained for $V E_{P}=95 \%$, in both the US and China (Figures S6B and S6D, respectively).

In the US, for $V E_{S}=95 \%$, the effectiveness of the vaccine in preventing infection (Figure 4A), severe disease (Figure 4B), critical disease (Figure 4C), and death (Figure 4D), was substantially enhanced by more rapid scale-up to reach $80 \%$ coverage, since the epidemic was already at high incidence at time vaccination was launched. Whereas in the US, only one vaccination was needed to avert one infection, provided that scale-up could be accomplished in 6 months, nearly 3 vaccinations were needed to avert one infection if the scale-up required 12 months. This, however, was not the case in China (Figure S7). Regardless of the speed of scale-up, only one vaccination was needed to avert one infection. 
medRxiv preprint doi: https://doi.org/10.1101/2021.01.07.21249380; this version posted January 8, 2021. The copyright holder for this preprint (which was not certified by peer review) is the author/funder, who has granted medRxiv a license to display the preprint in perpetuity.

All rights reserved. No reuse allowed without permission.

Figure 5 shows a comparison of the impact of vaccine scale-up duration on the number of vaccinations needed to avert one severe disease case (Figure 5A), one critical disease case (Figure 5B), and one death (Figure 5C), in the US, between the assumption of $V E_{S}=95 \%$ and that of $V E_{P}=95 \%$. As expected, a vaccine that prevents infection (and consequently disease) was superior to a vaccine preventing only disease. That superiority was even greater if scale-up is longer, where twice as many vaccinations were needed to avert each of these outcomes. Similar results were obtained for China (Figure S8).

In all of the above scenarios, it was assumed that easing of social restrictions would occur during six months following initiation of vaccination. However, as expected, a longer duration for easing restrictions resulted in a more favorable impact of vaccination, in both the US and China (Figure S9).

Uncertainty regarding the projected impact was small in the short-term for the US and China, in the first wave after vaccinations commenced, but it was large toward the end of 2021, as expected, due to uncertainty about persistence of the vaccine's protective immunity (Figure S10).

\section{Discussion}

The key conceptual finding that emerges from this study is that vaccine impact is strongly dependent on the difference between two essential metrics, "time to infection" and "time to vaccination." The competing "hazard" dynamics between the event of infection and the event of vaccination explain the variability of impact under the parameters considered: incidence at the onset of vaccination, duration of scale-up, vaccine coverage, or timing of the easing of restrictions. As the average time to vaccination is shortened relative to the average time to infection, by altering these parameters (by more rapid scale-up, slower easing of restrictions, or 
medRxiv preprint doi: https://doi.org/10.1101/2021.01.07.21249380; this version posted January 8, 2021. The copyright holder for this preprint (which was not certified by peer review) is the author/funder, who has granted medRxiv a license to display the preprint in perpetuity.

All rights reserved. No reuse allowed without permission.

reducing infection incidence through lockdowns or other restrictive measures), the impact would be more favorable, and fewer vaccinations would be needed to avert one infection or disease outcome.

A striking demonstration of this concept's importance can be seen in the case of a vaccine that does not prevent infection, but prevents disease with $V E_{P}=95 \%$ (Figures $\mathrm{S} 4$ and S5). This vaccine would not affect the time to infection in the population, and any easing of restrictions with vaccination will shorten the time to infection. Accordingly, such a vaccine, despite its $95 \%$ efficacy, would end up averting $<20 \%$ of disease cases and deaths in the US and $<50 \%$ in China. Since the time to infection in the US is much shorter than in China, as a consequence of the current high incidence rate, vaccine impact will be more favorable in China, where vaccination can be scaled up over a longer duration and still have superior impact to that in the US.

A consequence of the above findings is that vaccine impact will likely be heterogenous among nations. Countries with low or negligible incidence will benefit most from vaccination. Vaccine cost-effectiveness will be also optimized in such countries, with only one vaccination needed to avert one infection for a vaccine with $V E_{S}=95 \%$ (Figure S7).

Several other findings emerged from this study. Vaccination will flatten the epidemic curve, but may not prevent (or delay) a new wave, unless it is scaled up very rapidly (Figures 1-3). There is every virtue in rapidly scaling up vaccination, particularly in countries already suffering substantial incidence (Figure 3). Importantly, vaccination impact does not increase linearly with vaccine coverage - gains from vaccination would be proportionally higher if vaccine coverage exceeds $50 \%$ (Figure 3), stressing the importance of reaching high vaccine coverage. Easing of restrictions concurrently with vaccination can undermine many benefits of vaccination, as more people are likely to become infected before they are vaccinated. Easing of restrictions needs to 
medRxiv preprint doi: https://doi.org/10.1101/2021.01.07.21249380; this version posted January 8, 2021. The copyright holder for this preprint (which was not certified by peer review) is the author/funder, who has granted medRxiv a license to display the preprint in perpetuity.

All rights reserved. No reuse allowed without permission.

be slow and gradual, tailored to the epidemiologic situation in each country (Figure S9). For instance, with its ongoing high incidence, easing of restrictions is not warranted in the US, while vaccination is scaled up.

With 95\% efficacy, COVID-19 vaccination is very cost-effective, as fewer than 3 vaccinations are needed to avert one infection, and this effectiveness can be optimized further with more rapid scale-up (Figure 4 and Figure S7). The impact of vaccination in averting disease or death is twofold higher for a vaccine that prevents infection, compared to a vaccine that only prevents disease (Figures 1-2 versus Figures S4-S5). This is because preventing infection not only prevents disease directly, but also reduces infection circulation; thus, also indirectly reducing disease. Moreover, twice as many vaccinations are needed to avert one disease or death outcome for a vaccine that prevents only disease, compared to one that prevents infection (Figure 5 and Figure S8).

This study has some limitations. Model estimations are contingent on the validity and generalizability of input data. While we used available evidence for SARS-CoV-2 natural history and epidemiology, our understanding of its epidemiology is still evolving. All age groups were assumed equally susceptible to infection, but evidence suggests some biological differences in susceptibility [24-31]. The exact extent of exposure to the infection in both the US and China is unknown, but plays an important role in vaccine impact. From an epidemiological perspective, we assumed that $20 \%$ of the US population and a negligible percentage of the Chinese population have been already infected, but vaccine impact can be quite different if such assumptions prove unrealistic. Vaccinated persons were assumed to be immediately protected, once vaccinated, but in reality, vaccine protection develops over the course of a month following inoculation $[7,8]$. Two parameters remain unknown, despite being critical to the longer-term 
medRxiv preprint doi: https://doi.org/10.1101/2021.01.07.21249380; this version posted January 8, 2021. The copyright holder for this preprint (which was not certified by peer review) is the author/funder, who has granted medRxiv a license to display the preprint in perpetuity.

All rights reserved. No reuse allowed without permission.

impact of vaccination: durations of vaccine protection and natural immunity. If both prove to be relatively brief, the impact of the vaccine will be diminished and it may be necessary to periodically re-immunize, or to develop additional vaccines that protect against other circulating strains of this virus.

\section{Conclusions}

COVID-19 vaccination can have an immense impact on averting infection and/or disease. It can substantially flatten and delay future epidemic waves (if not prevent them altogether), and will be highly cost-effective, given the small number of vaccinations needed to avert one infection or one disease outcome. However, the impact of vaccination is likely to vary among countries, reflecting an underlying "epidemiological inequity", as the epidemic phase in those countries also varies. Nations that will benefit most from vaccination are those where waiting time before vaccination is much shorter than time to infection, that is countries currently at low incidence, such as China. For countries at high incidence, the impact may prove far less than current expectations, despite the vaccine's $95 \%$ efficacy, if vaccination is scaled up slowly and/or if restrictions are eased prematurely. For countries such as the US, there is every virtue in scaling up vaccination rapidly, reaching high vaccine coverage, and delaying any easing of restrictions until viral incidence reaches low levels. 
medRxiv preprint doi: https://doi.org/10.1101/2021.01.07.21249380; this version posted January 8, 2021. The copyright holder for this preprint (which was not certified by peer review) is the author/funder, who has granted medRxiv a license to display the preprint in perpetuity.

Figure 1. Impact of SARS-CoV-2 vaccination on numbers of A) new infections, B) new severe disease cases, $C$ ) new critical disease cases, and D) new deaths in the United States. The vaccine is assumed to have an efficacy of $95 \%$ against infection and is introduced on January 1,2021 , when the proportion of the population already infected is $20 \%$. Vaccine coverage is scaled up to reach $80 \%$ by December 31, 2021. Duration of both vaccine protection and natural immunity is one year. This scenario assumes an $R_{0}$ of 1.2 on January 1, 2021, which increases with gradual easing of restrictions to reach 4.0 after six months. Results of a scenario assuming that the vaccine has no efficacy against infection, but an efficacy of $95 \%$ against severe and critical disease are shown in Figure S4.

\section{United States}

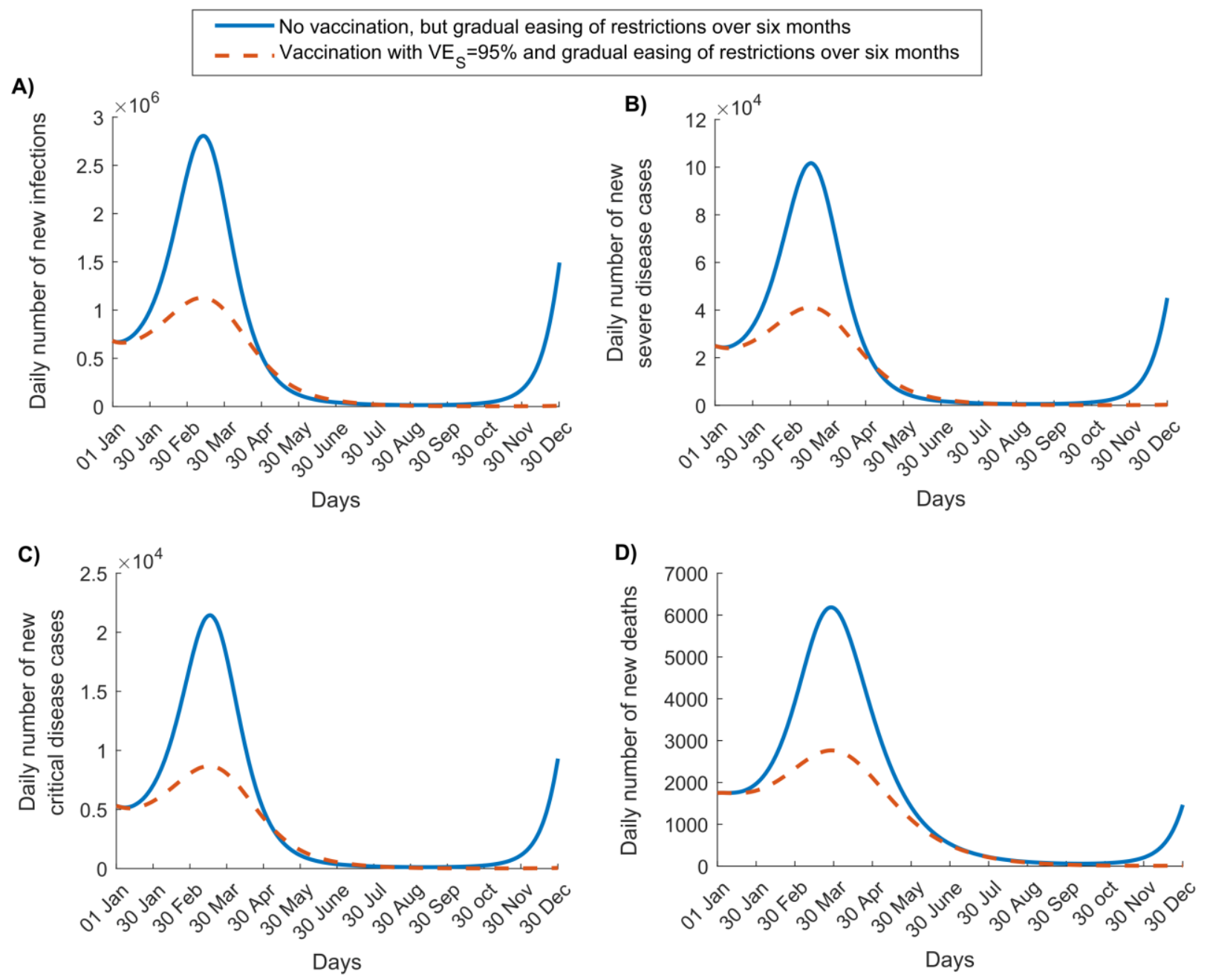


medRxiv preprint doi: https://doi.org/10.1101/2021.01.07.21249380; this version posted January 8, 2021. The copyright holder for this preprint (which was not certified by peer review) is the author/funder, who has granted medRxiv a license to display the preprint in perpetuity.

Figure 2. Impact of SARS-CoV-2 vaccination on numbers of A) new infections, B) new severe disease cases, $C$ ) new critical disease cases, and $D$ ) new deaths in China. The vaccine is assumed to have an efficacy of 95\% against infection and is introduced on January 1, 2021. Vaccine coverage is scaled up to reach $80 \%$ by December 31, 2021. Duration of both vaccine protection and natural immunity is one year. This scenario assumes an $R_{0}$ of 1.0 on January 1 , 2021, which increases with gradual easing of restrictions, to reach 4.0 after six months. Results of a scenario assuming that the vaccine has no efficacy against infection, but an efficacy of $95 \%$ against severe and critical disease are shown in Figure S5.

\section{China}
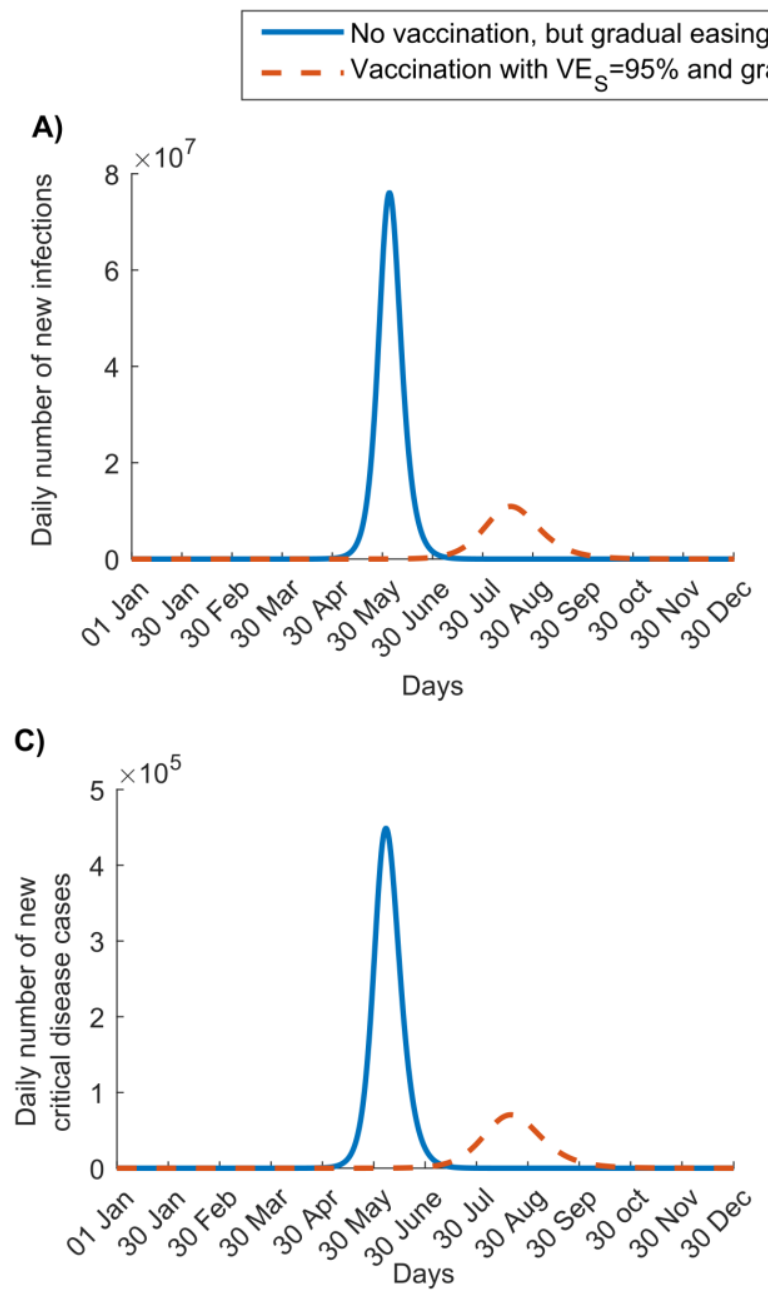

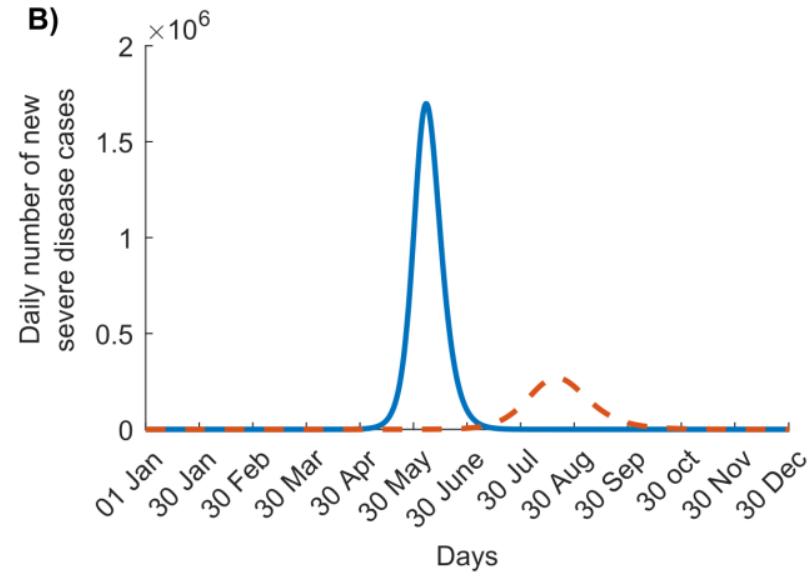

D)

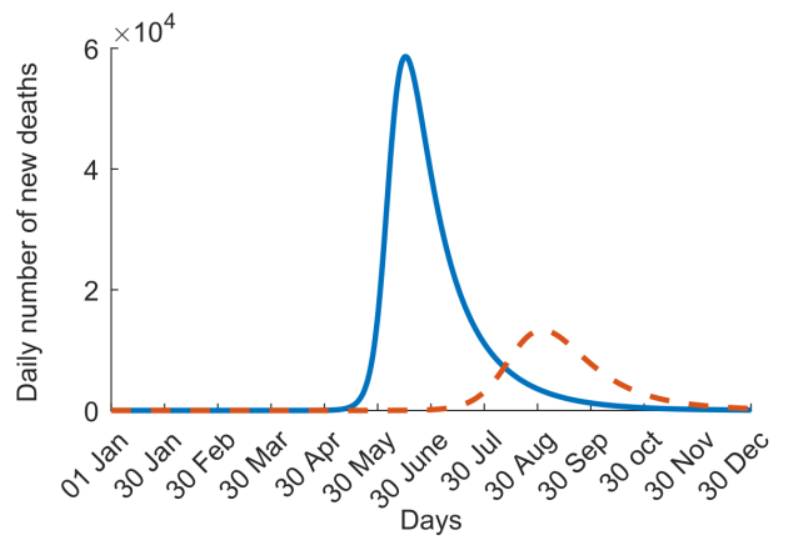


medRxiv preprint doi: https://doi.org/10.1101/2021.01.07.21249380; this version posted January 8, 2021. The copyright holder for this preprint (which was not certified by peer review) is the author/funder, who has granted medRxiv a license to display the preprint in perpetuity.

Figure 3. Impact of vaccine scale-up duration and vaccine coverage on numbers of averted severe and critical disease cases for a vaccine that protects against both infection and disease. Cumulative averted severe and critical disease cases in A) the United States and C) China at different vaccination scale-up durations to reach $80 \%$ coverage. Cumulative averted severe and critical disease cases in B) the United States and D) China at varying levels of vaccine coverage. The vaccine is assumed to have an efficacy of $95 \%$ against infection and is introduced on January 1, 2021, when the cumulative proportion of the population infected is $20 \%$ in the United States and $0 \%$ in China. Duration of both vaccine protection and natural immunity is one year. This scenario assumes gradual easing of restrictions within 6 months. The results of a scenario assuming the vaccine has no efficacy against infection, but an efficacy of $95 \%$ against severe and critical disease is shown in Figure S6.

\section{United States}

A)

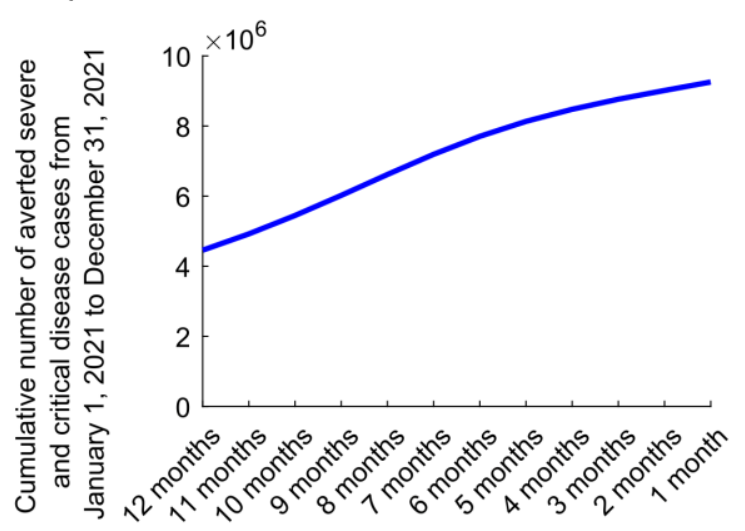

B)

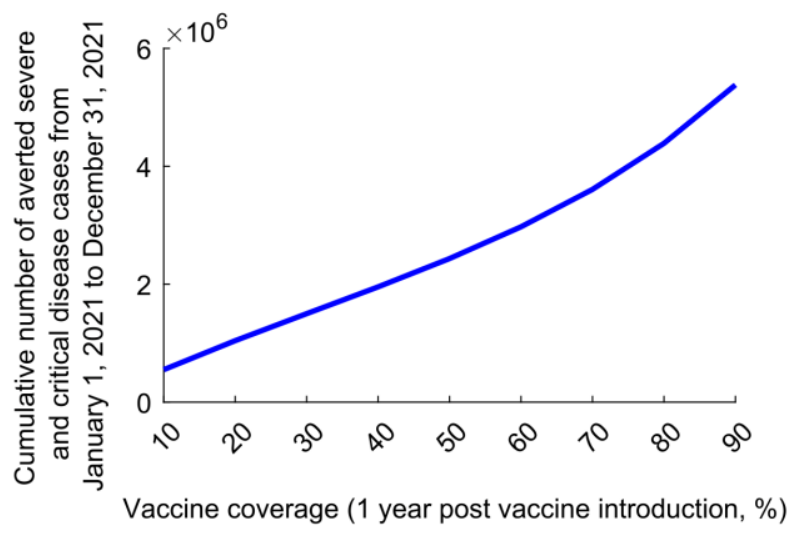

Scale-up duration for the vaccine to reach $80 \%$ coverage

C)

\section{China}

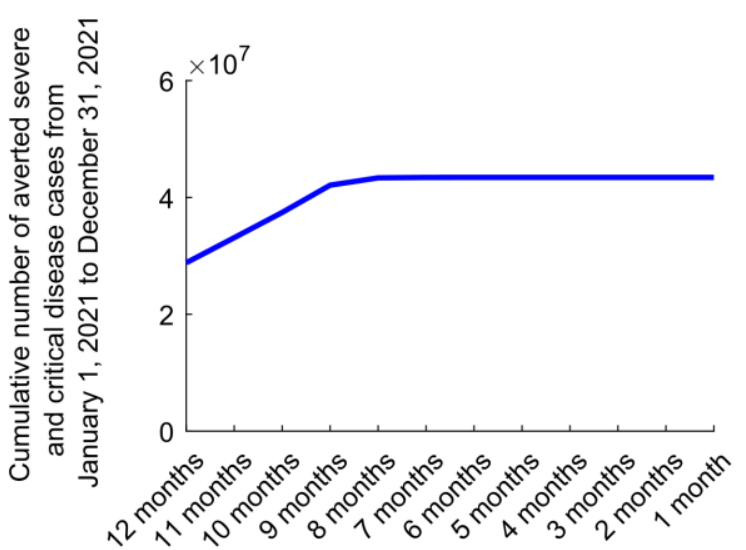

Scale-up duration for the vaccine to reach $80 \%$ coverage
D)

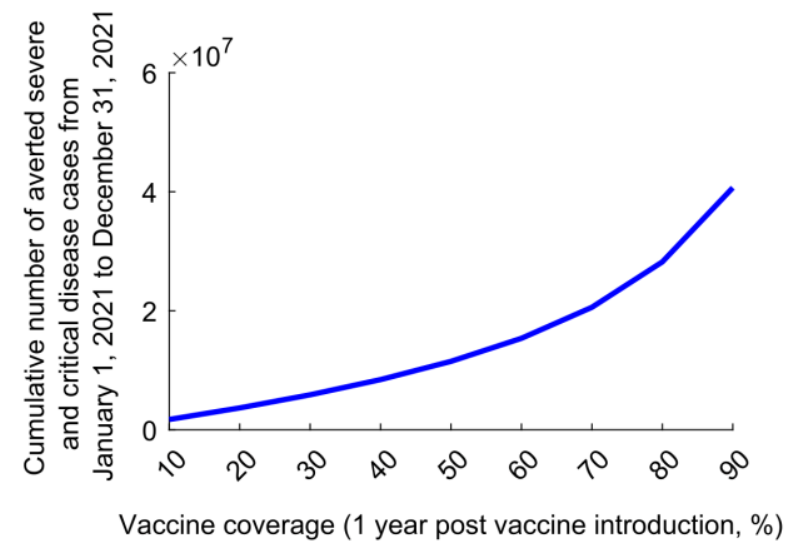


medRxiv preprint doi: https://doi.org/10.1101/2021.01.07.21249380; this version posted January 8, 2021. The copyright holder for this preprint (which was not certified by peer review) is the author/funder, who has granted medRxiv a license to display the preprint in perpetuity.

All rights reserved. No reuse allowed without permission.

Figure 4. Impact of vaccine scale-up duration on the number of vaccinations needed to avert one infection (A), one severe disease case $(B)$, one critical disease case $(C)$, and one death (D) in the United States. The vaccine is assumed to have an efficacy of $95 \%$ against infection and is introduced on January 1, 2021, when the cumulative proportion of the population infected is $20 \%$. Duration of both vaccine protection and natural immunity is one year. This scenario assumes a gradual easing of restrictions within 6 months. Corresponding results for China are shown in Figure S7.

\section{United States}

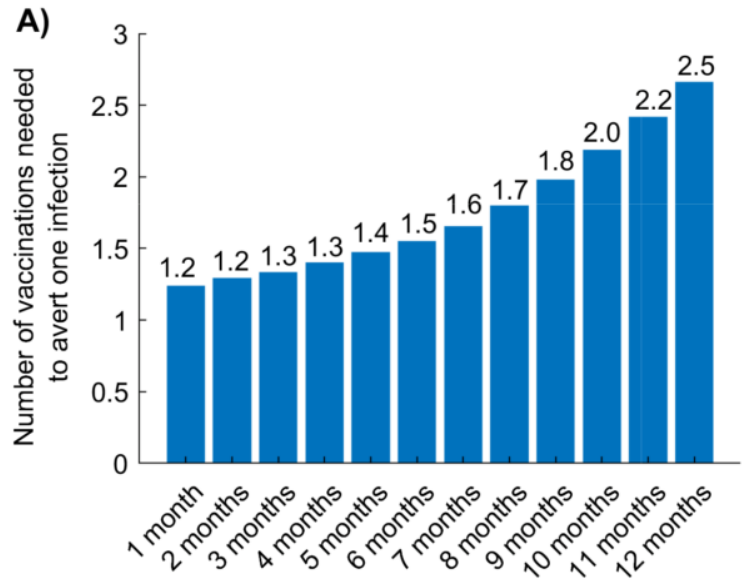

Scale-up duration for the vaccine to reach $80 \%$ coverage

\section{C)}

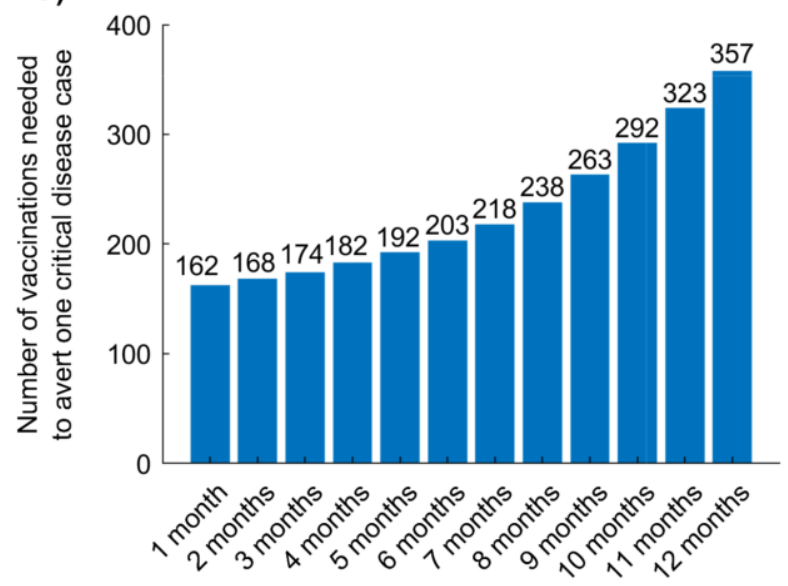

Scale-up duration for the vaccine to reach $80 \%$ coverage

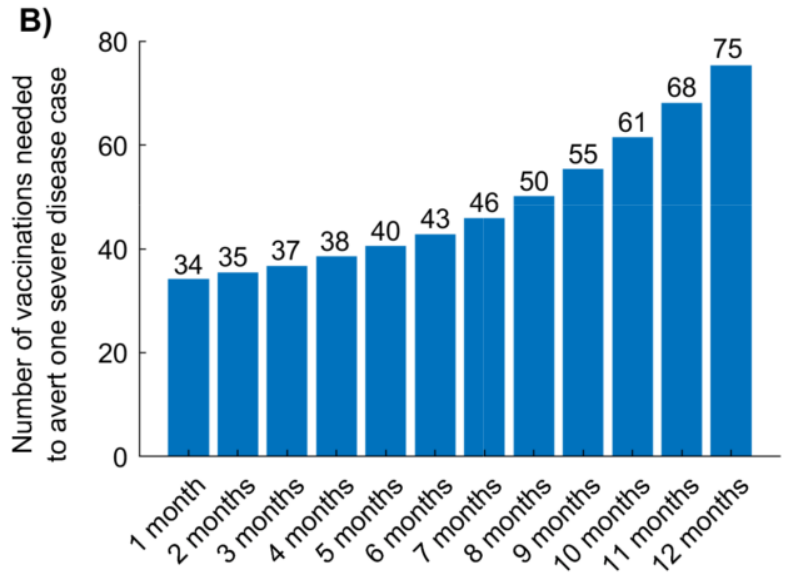

Scale-up duration for the vaccine to reach $80 \%$ coverage

D)

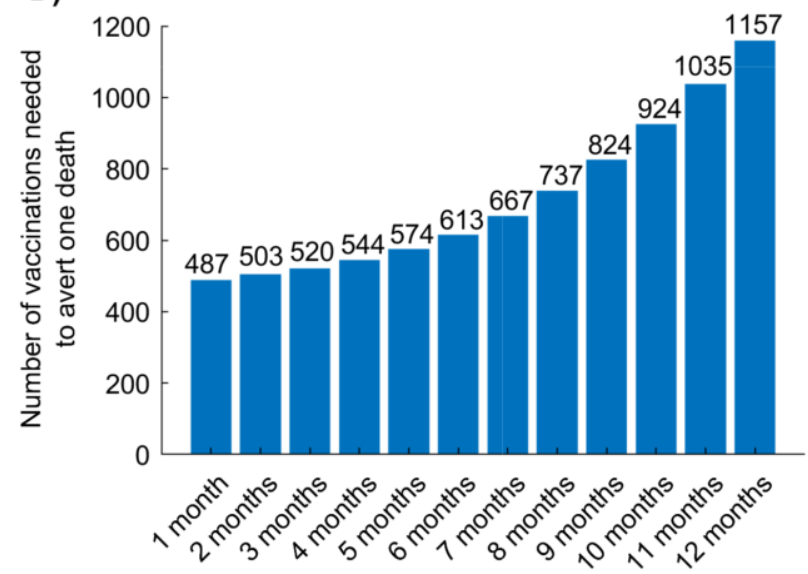

Scale-up duration for the vaccine to reach $80 \%$ coverage 
medRxiv preprint doi: https://doi.org/10.1101/2021.01.07.21249380; this version posted January 8, 2021. The copyright holder for this preprint (which was not certified by peer review) is the author/funder, who has granted medRxiv a license to display the preprint in perpetuity.

All rights reserved. No reuse allowed without permission.

Figure 5. Comparison of the impact of a vaccine acting against infection ( $V E_{S}$ efficacy) versus a vaccine acting only against disease ( $V E_{P}$ efficacy) in the United States. The number of vaccinations needed to avert one severe disease case (A), one critical disease case (B), and one death $(\mathrm{C})$, for a vaccine with $V E_{S}=95 \%$ versus a vaccine with $V E_{P}=95 \%$. The vaccine is introduced on January 1, 2021, when the cumulative proportion of the population infected is $20 \%$. Duration of both vaccine protection and natural immunity is one year. This scenario assumes a gradual easing of restrictions within 6 months. Corresponding results for China are shown in Figure S8.

A)
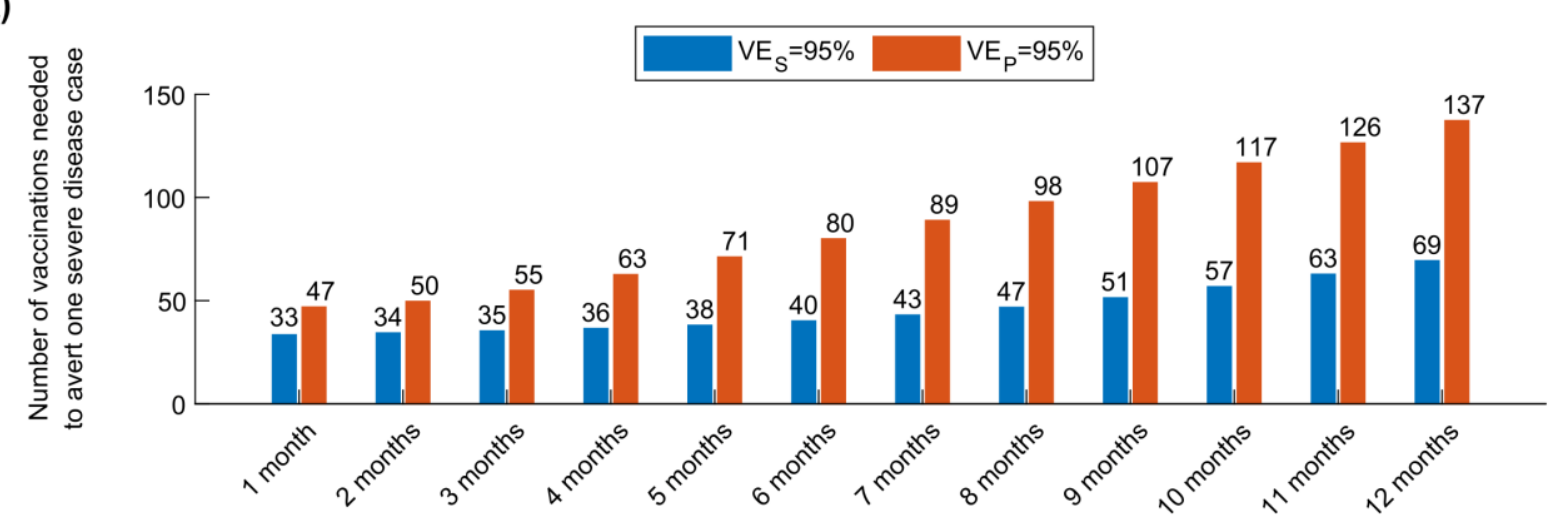

B)
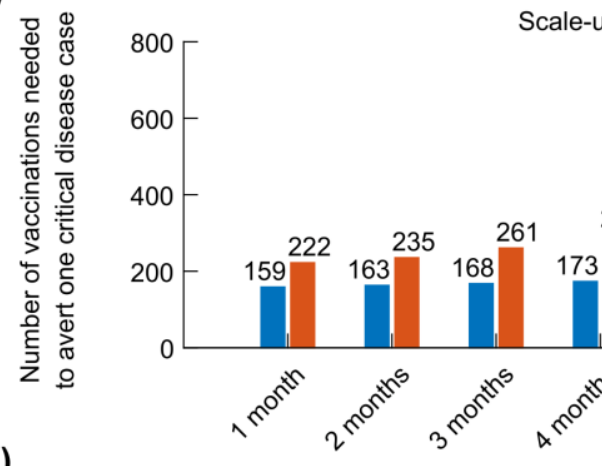

Scale-up duration for the vaccine to reach $80 \%$ coverage

C)

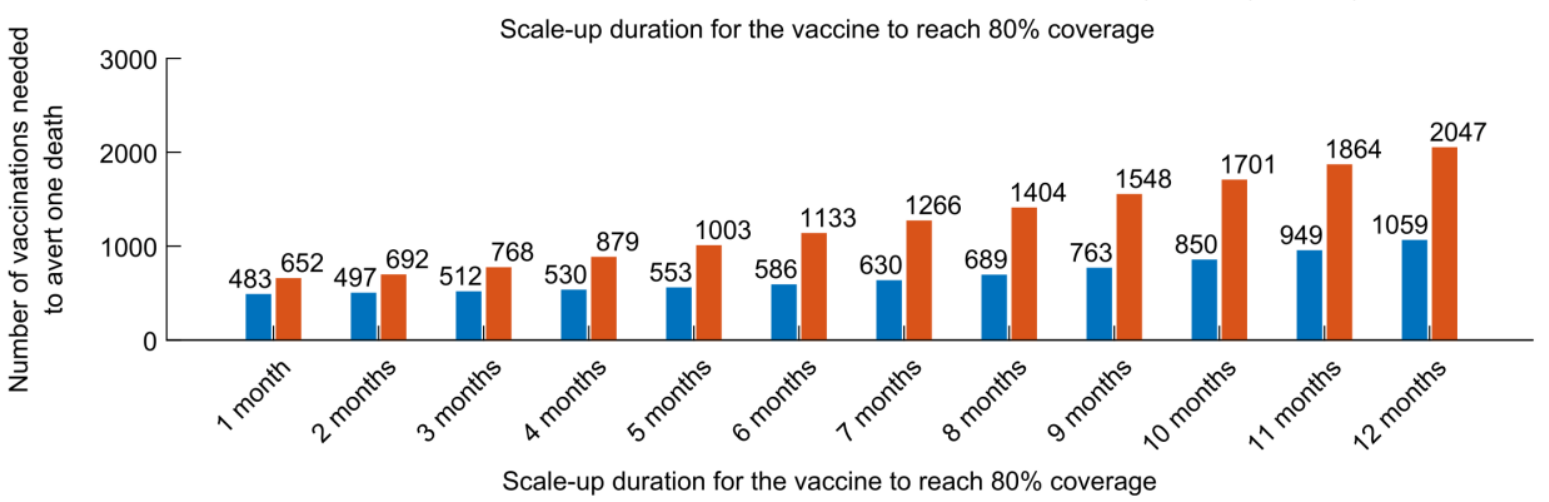


medRxiv preprint doi: https://doi.org/10.1101/2021.01.07.21249380; this version posted January 8, 2021. The copyright holder for this preprint (which was not certified by peer review) is the author/funder, who has granted medRxiv a license to display the preprint in perpetuity.

All rights reserved. No reuse allowed without permission.

Author contributions: MM constructed, coded, and parameterized the mathematical model, conducted the analyses, and co-wrote the first draft of the paper. HC supported model parametrization and analyses and co-wrote the first draft of the paper. LJA conceived and led the design of the study and its implementation, and co-wrote the first draft of the paper. All authors contributed to discussion and interpretation of results and to writing of the manuscript. All authors have read and approved the final manuscript.

Funding: The developed mathematical models were made possible by NPRP grant number 9040-3-008 (Principal investigator: LJA) and NPRP grant number 12S-0216-190094 (Principal investigator: LJA) from the Qatar National Research Fund (a member of Qatar Foundation; https://www.qnrf.org). The statements made herein are solely the responsibility of the authors. The funders had no role in study design, data collection and analysis, decision to publish, or preparation of the manuscript.

Acknowledgments: The authors are grateful for support provided by the Biomedical Research Program and the Biostatistics, Epidemiology, and Biomathematics Research Core, both at Weill Cornell Medicine-Qatar.

Conflicts of Interest: The authors declare that they have no competing interests.

Data and materials availability: All data are available in the manuscript and its supplementary materials. Code programmed in MATLAB can be obtained from the authors. 


\section{References}

1. COVID-19 Outbreak Live Update. Available from: https://www.worldometers.info/coronavirus/. Accessed on November 11, 2020. 2020.

2. United Nations. Shared responsibility, global solidarity: Responding to the socio-economic impacts of COVID-19. Available from: https://www.un.org/sites/un2.un.org/files/sg_report_socioeconomic_impact_of_covid19.pdf. Accessed on: April 16, 2020. 2020.

3. Kaplan J.; Frias L.; McFall-Johnsen M. A third of the global population is on coronavirus lockdown. Available from: https://www.businessinsider.com.au/countries-on-lockdown-coronavirus-italy-2020-3 Accessd on: April 25, 2020. Business Insider Australia 2020.

4. Gilardino, R.E. Does "flattening the curve" affect critical care services delivery for COVID-19? A global health perspective. International Journal of Health Policy and Management 2020, 9, 503-507, doi:10.34172/IJHPM.2020.117.

5. BBC news. Coronavirus: The world in lockdown in maps and charts. Available from: https://www.bbc.com/news/world-52103747. Acccessed on: April 25, 2020. 2020.

6. $\quad$ Makhoul M.; Ayoub H.H.; Chemaitelly H.; Seedat S.; Mumtaz G.R.; Al-Omari S.; Abu-Raddad L.J. Epidemiological impact of SARS-CoV-2 vaccination: Mathematical modeling analyses. Vaccines 2020, 8 , doi:10.3390/vaccines8040668.

7. Jackson, L.A.; Anderson, E.J.; Rouphael, N.G.; Roberts, P.C.; Makhene, M.; Coler, R.N.; McCullough, M.P.; Chappell, J.D.; Denison, M.R.; Stevens, L.J., et al. An mRNA Vaccine against SARS-CoV-2 Preliminary Report. N Engl J Med 2020, 383, 1920-1931, doi:10.1056/NEJMoa2022483.

8. Polack, F.P.; Thomas, S.J.; Kitchin, N.; Absalon, J.; Gurtman, A.; Lockhart, S.; Perez, J.L.; Perez Marc, G.; Moreira, E.D.; Zerbini, C., et al. Safety and Efficacy of the BNT162b2 mRNA Covid-19 Vaccine. $N$ Engl J Med 2020, 10.1056/NEJMoa2034577, doi:10.1056/NEJMoa2034577.

9. MATLAB®. The Language of Technical Computing. The MathWorks, Inc. 2019.

10. Abu-Raddad, L.J.; Chemaitelly, H.; Malek, J.A.; Ahmed, A.A.; Mohamoud, Y.A.; Younuskunju, S.; Ayoub, H.H.; Al Kanaani, Z.; Al Khal, A.; Al Kuwari, E., et al. Assessment of the risk of SARS-CoV-2 reinfection in an intense re-exposure setting. Clinical Infectious Diseases 2020. ciaa1846. doi:

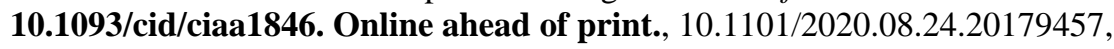
doi:10.1101/2020.08.24.20179457.

11. Tillett, R.L.; Sevinsky, J.R.; Hartley, P.D.; Kerwin, H.; Crawford, N.; Gorzalski, A.; Laverdure, C.; Verma, S.C.; Rossetto, C.C.; Jackson, D., et al. Genomic evidence for reinfection with SARS-CoV-2: a case study. Lancet Infect Dis 2020, 10.1016/S1473-3099(20)30764-7, doi:10.1016/S1473-3099(20)30764-7.

12. To, K.K.; Hung, I.F.; Ip, J.D.; Chu, A.W.; Chan, W.M.; Tam, A.R.; Fong, C.H.; Yuan, S.; Tsoi, H.W.; Ng, A.C., et al. COVID-19 re-infection by a phylogenetically distinct SARS-coronavirus-2 strain confirmed by whole genome sequencing. Clin Infect Dis 2020, 10.1093/cid/ciaa1275, doi:10.1093/cid/ciaa1275.

13. Van Elslande, J.; Vermeersch, P.; Vandervoort, K.; Wawina-Bokalanga, T.; Vanmechelen, B.; Wollants, E.; Laenen, L.; Andre, E.; Van Ranst, M.; Lagrou, K., et al. Symptomatic SARS-CoV-2 reinfection by a phylogenetically distinct strain. Clin Infect Dis 2020, 10.1093/cid/ciaa1330, doi:10.1093/cid/ciaa1330.

14. Prado-Vivar B.; Becerra-Wong M.; Guadalupe J.J.; Marquez S.; Gutierrez B.; Rojas-Silva P.; Trueba G.; Barragan V.; Cardenas P. COVID-19 re-infection by a phylogenetically distinct SARS-CoV-2 variant, first confirmed event in South America. SSRN. 2020; (published online Sept 8.) (preprint) https://doi.org/10.2139/ssrn.3686174.

15. Kissler, S.M.; Tedijanto, C.; Goldstein, E.; Grad, Y.H.; Lipsitch, M. Projecting the transmission dynamics of SARS-CoV-2 through the postpandemic period. Science 2020, 10.1126/science.abb5793, doi:10.1126/science.abb5793.

16. Salje, H.; Tran Kiem, C.; Lefrancq, N.; Courtejoie, N.; Bosetti, P.; Paireau, J.; Andronico, A.; Hoze, N.; Richet, J.; Dubost, C.L., et al. Estimating the burden of SARS-CoV-2 in France. Science 2020, 10.1126/science.abc3517, eabc3517, doi:10.1126/science.abc3517.

17. United Nations Department of Economic and Social Affairs Population Dynamics. The 2019 Revision of World Population Prospects. Available from https://population.un.org/wpp/. Accessed on March 1st, 2020. 2020.

18. Voysey, M.; Clemens, S.A.C.; Madhi, S.A.; Weckx, L.Y.; Folegatti, P.M.; Aley, P.K.; Angus, B.; Baillie, V.L.; Barnabas, S.L.; Bhorat, Q.E., et al. Safety and efficacy of the ChAdOx1 nCoV-19 vaccine 
(AZD1222) against SARS-CoV-2: an interim analysis of four randomised controlled trials in Brazil, South Africa, and the UK. Lancet 2020, 10.1016/S0140-6736(20)32661-1, doi:10.1016/S0140-6736(20)32661-1.

19. He, W.; Yi, G.Y.; Zhu, Y. Estimation of the basic reproduction number, average incubation time, asymptomatic infection rate, and case fatality rate for COVID-19: Meta-analysis and sensitivity analysis. $J$ Med Virol 2020, 10.1002/jmv.26041, doi:10.1002/jmv.26041.

20. MIDAS Online COVID-19 Portal. COVID-19 parameter estimates: basic reproduction number. Available from: https://github.com/midas-network/COVID19/tree/master/parameter_estimates/2019_novel_coronavirus. Accessed on: May 19, 2020. 2020.

21. World Health Organization. Report of the WHO-China Joint Mission on Coronavirus Disease 2019 (COVID-19). Available from :https://www.who.int/docs/default-source/coronaviruse/who-china-jointmission-on-covid-19-final-report.pdf. Accessed on March 10, 2020; 2020.

22. Mckay, M.D.; Beckman, R.J.; Conover, W.J. A Comparison of Three Methods for Selecting Values of Input Variables in the Analysis of Output from a Computer Code. Technometrics 1979, 21, 239-245, doi:Doi 10.2307/1268522.

23. Sanchez, M.A.; Blower, S.M. Uncertainty and sensitivity analysis of the basic reproductive rate Tuberculosis as an example. Am J Epidemiol 1997, 145, 1127-1137.

24. Ayoub, H.H.; Chemaitelly, H.; Mumtaz, G.R.; Seedat, S.; Awad, S.F.; Makhoul, M.; Abu-Raddad, L.J. Characterizing key attributes of the epidemiology of COVID-19 in China: Model-based estimations. Global Epidemiology 2020, 100042, doi:https://doi.org/10.1016/j.gloepi.2020.100042.

25. Davies, N.G.; Klepac, P.; Liu, Y.; Prem, K.; Jit, M.; group, C.C.-w.; Eggo, R.M. Age-dependent effects in the transmission and control of COVID-19 epidemics. Nat Med 2020, 10.1038/s41591-020-0962-9, doi:10.1038/s41591-020-0962-9.

26. Mizumoto, K.; Omori, R.; Nishiura, H. Age specificity of cases and attack rate of novel coronavirus disease (COVID-19). medRxiv 2020, 10.1101/2020.03.09.20033142, 2020.2003.2009.20033142, doi:10.1101/2020.03.09.20033142.

27. Zhu, Y.; Bloxham, C.J.; Hulme, K.D.; Sinclair, J.E.; Tong, Z.W.M.; Steele, L.E.; Noye, E.C.; Lu, J.; Chew, K.Y.; Pickering, J., et al. Children are unlikely to have been the primary source of household SARS-CoV-2 infections. medRxiv 2020, 10.1101/2020.03.26.20044826, 2020.2003.2026.20044826, doi:10.1101/2020.03.26.20044826.

28. Colson, P.; Tissot-Dupont, H.; Morand, A.; Boschi, C.; Ninove, L.; Esteves-Vieira, V.; Gautret, P.; Brouqui, P.; Parola, P.; Lagier, J.C., et al. Children account for a small proportion of diagnoses of SARSCoV-2 infection and do not exhibit greater viral loads than adults. Eur J Clin Microbiol Infect Dis 2020, 39, 1983-1987, doi:10.1007/s10096-020-03900-0.

29. Macartney, K.; Quinn, H.E.; Pillsbury, A.J.; Koirala, A.; Deng, L.; Winkler, N.; Katelaris, A.L.; O'Sullivan, M.V.N.; Dalton, C.; Wood, N., et al. Transmission of SARS-CoV-2 in Australian educational settings: a prospective cohort study. Lancet Child Adolesc Health 2020, 10.1016/S2352-4642(20)30251-0, doi:10.1016/S2352-4642(20)30251-0.

30. Goldstein, E.; Lipsitch, M.; Cevik, M. On the effect of age on the transmission of SARS-CoV-2 in households, schools and the community. medRxiv 2020, 10.1101/2020.07.19.20157362, doi:10.1101/2020.07.19.20157362.

31. Merckx, J.; Labrecque, J.A.; Kaufman, J.S. Transmission of SARS-CoV-2 by Children. Dtsch Arztebl Int 2020, 117, 553-560, doi:10.3238/arztebl.2020.0553. 


\section{Supplementary Material}

\section{Epidemiological differences in the impact of COVID-19 vaccination in the United States and China}

Monia Makhoul ${ }^{1,2,3}$, Hiam Chemaitelly ${ }^{1,2}$, Houssein H. Ayoub ${ }^{4}$, Shaheen Seedat ${ }^{1,2,3}$, and Laith J. Abu-Raddad ${ }^{1,2.3 *}$

${ }^{1}$ Infectious Disease Epidemiology Group, Weill Cornell Medicine-Qatar, Cornell University, Qatar Foundation - Education City, Doha, Qatar

${ }^{2}$ World Health Organization Collaborating Centre for Disease Epidemiology Analytics on HIV/AIDS, Sexually Transmitted Infections, and Viral Hepatitis, Weill Cornell Medicine-Qatar, Cornell University, Qatar Foundation - Education City, Doha, Qatar

${ }^{3}$ Department of Population Health Sciences, Weill Cornell Medicine, Cornell University, New York City, New York, USA

${ }^{4}$ Department of Mathematics, Statistics, and Physics, Qatar University, Doha, Qatar

*To whom correspondence should be addressed: Email: 1ja2002@qatar-med.cornell.edu 
medRxiv preprint doi: https://doi.org/10.1101/2021.01.07.21249380; this version posted January 8, 2021. The copyright holder for this preprint (which was not certified by peer review) is the author/funder, who has granted medRxiv a license to display the preprint in perpetuity.

All rights reserved. No reuse allowed without permission.

\section{Table of Contents}

Text S1A. Model Structure

Figure S1. Schematic diagram describing the SARS-CoV-2 transmission dynamics in presence of a vaccine that reduces susceptibility to infection ......

Table S1. Definitions of population variables and symbols used in the model

Text S1B. Model adjustment for a vaccine that reduces only severe and critical disease .........................................8

Figure S2. Schematic diagram describing the SARS-CoV-2 transmission dynamics in presence of a vaccine that reduces severe and critical disease, but does not prevent infection

Figure S3. Distribution of waning of natural infection and vaccine immunity

Text S1C. Parameter values.

Table S2. Model assumptions in terms of parameter values

Figure S4. Impact of SARS-CoV-2 vaccination on number of A) new infections, B) new severe disease cases, C) new critical disease cases, and D) new deaths in the United States

Figure S5. Impact of SARS-CoV-2 vaccination on number of A) new infections, B) new severe disease cases, C) new critical disease cases, and D) new deaths in China

Figure S6. Impact of vaccine scale-up duration and vaccine coverage on number of averted severe and critical disease cases for a vaccine that protects only against disease

Figure S7. Impact of vaccine scale-up duration on number of vaccinations needed to avert one infection (A), one severe disease case (B), one critical disease case (C), and one death (D), in China

Figure S8. Comparison of the impact of a vaccine acting against infection ( $V E_{S}$ efficacy) versus a vaccine acting only against disease ( $V E_{P}$ efficacy) in China.

Figure S9: Impact of the duration of easing of the social and physical distancing restrictions on number of averted severe and critical disease cases

Figure S10. Uncertainty analyses 


\section{Text S1. SARS-CoV-2 vaccine mathematical model}

\section{A. Model structure}

We extended a recently-developed age-structured deterministic compartmental model [1-5] to describe the impact of vaccination on the severe acute respiratory syndrome coronavirus 2 (SARS-CoV-2) transmission dynamics and progression of the resulting disease, Coronavirus Disease 2019 (COVID-2019), in a given population. The model stratifies the unvaccinated and vaccinated populations into compartments according to age group $(0-9,10-19,20-29, \ldots, \geq 80$ years), infection status (uninfected, infected), infection stage (mild, severe, critical), disease stage (severe, critical), and compartments for the gamma distribution ( $\Gamma$-distribution) describing the waning of natural and vaccine immunity.

Transmission and disease progression dynamics in the vaccinated and unvaccinated cohorts are described in the model using age-specific sets of nonlinear ordinary differential equations, where each age group $a(a=1,2, \ldots 9)$ refers to a 10 -year age band $(0-9,10-19, . .70-79)$ apart from the last group including all those aged $\geq 0$ years. The model is illustrated in Figure S1. 
Figure S1. Schematic diagram describing the SARS-CoV-2 transmission dynamics model in presence of a vaccine that reduces susceptibility to infection.

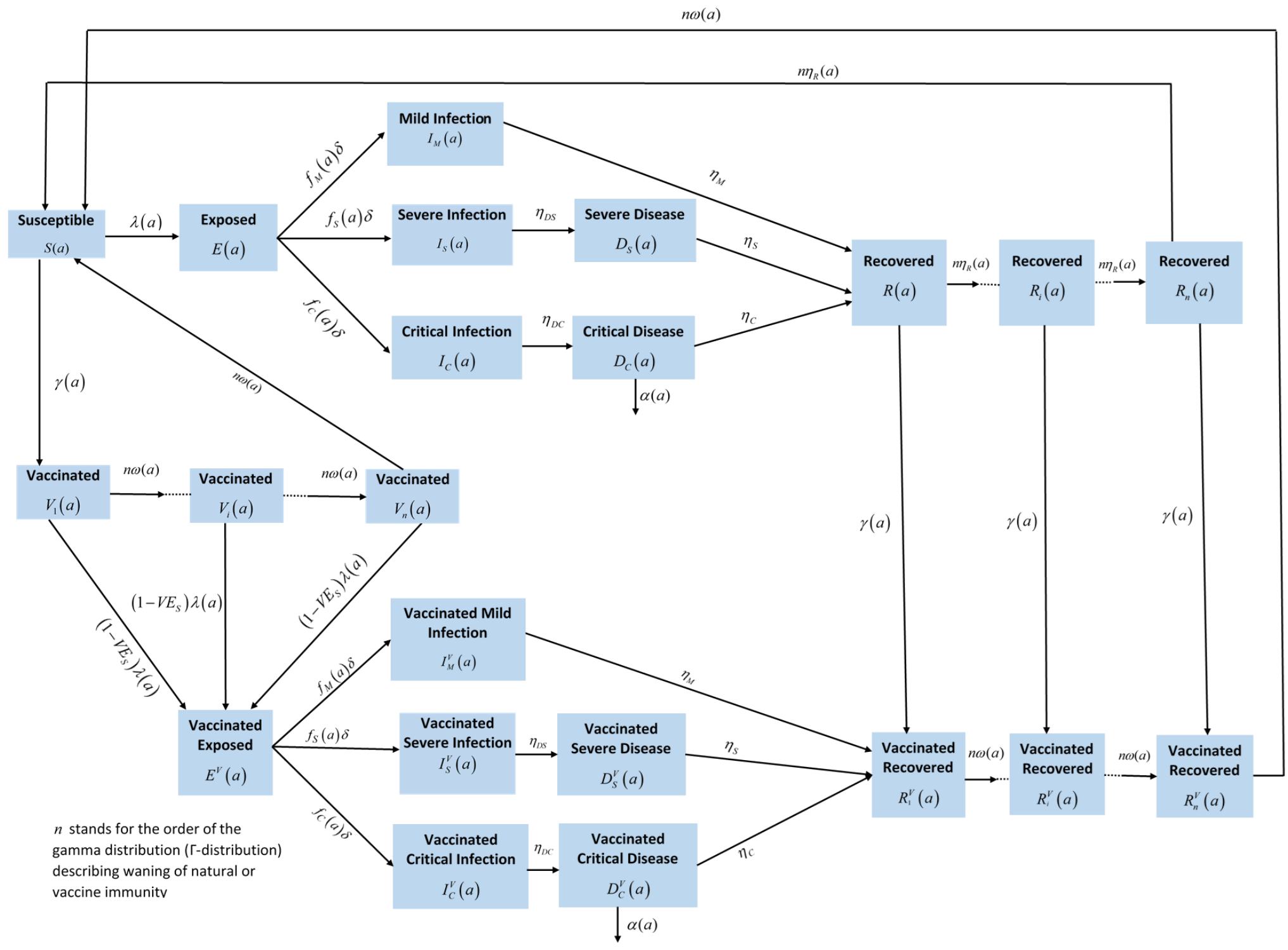


Unvaccinated population:

$$
\begin{aligned}
& \frac{d S(a)}{d t}=\xi(a-1) S(a-1)-(\lambda(a)+\mu+\xi(a)+\gamma(a)) S(a)+n \omega(a)\left(V_{n}(a)+R_{n}^{V}(a)\right)+n \eta_{R} R_{n}(a) \\
& \frac{d E(a)}{d t}=\xi(a-1) E(a-1)+\lambda(a) S(a)-(\delta+\mu+\xi(a)) E(a) \\
& \frac{d I_{M}(a)}{d t}=\xi(a-1) I_{M}(a-1)+f_{M}(a) \delta E(a)-\left(\eta_{M}+\mu+\xi(a)\right) I_{M}(a) \\
& \frac{d I_{S}(a)}{d t}=\xi(a-1) I_{S}(a-1)+f_{S}(a) \delta E(a)-\left(\eta_{D S}+\mu+\xi(a)\right) I_{S}(a) \\
& \frac{d I_{C}(a)}{d t}=\xi(a-1) I_{C}(a-1)+f_{C}(a) \delta E(a)-\left(\eta_{D C}+\mu+\xi(a)\right) I_{C}(a) \\
& \frac{d D_{S}(a)}{d t}=\xi(a-1) D_{S}(a-1)+\eta_{D S} I_{S}(a)-\left(\eta_{S}+\mu+\xi(a)\right) D_{S}(a) \\
& \frac{d D_{C}(a)}{d t}=\xi(a-1) D_{C}(a-1)+\eta_{D C} I_{C}(a)-\left(\eta_{C}+\mu+\xi(a)+\alpha(a)\right) D_{C}(a) \\
& \frac{d R_{1}(a)}{d t}=\xi(a-1) R_{1}(a-1)+\eta_{M} I_{M}(a)+\eta_{S} D_{S}(a)+\eta_{C} D_{C}(a)-\left(\mu+\xi(a)+\gamma(a)+n \eta_{R}\right) R_{1}(a)
\end{aligned}
$$

For $\mathrm{k}=2, . . \mathrm{n}$

$$
\frac{d R_{k}(a)}{d t}=\xi(a-1) R_{k}(a-1)+n \eta_{R} R_{k-1}(a)-\left(\mu+\xi(a)+\gamma(a)+n \eta_{R}\right) R_{k}(a)
$$

Vaccinated populations aged 10+ years:

$$
\frac{d V_{1}(a)}{d t}=\xi(a-1) V_{1}(a-1)+\gamma(a) S(a)-\left(\left(1-V E_{S}\right) \lambda(a)+\mu+\xi(a)+n \omega(a)\right) V_{1}(a)
$$

$\underline{\text { For } \mathrm{k}=2, \ldots \mathrm{n}}$

$$
\begin{aligned}
& \frac{d V_{k}(a)}{d t}=\xi(a-1) V_{k}(a-1)+n \omega(a) V_{k-1}(a)-\left(\left(1-V E_{S}\right) \lambda(a)+\mu+\xi(a)+n \omega(a)\right) V_{k}(a) \\
& \frac{d E^{V}(a)}{d t}=\xi(a-1) E^{V}(a-1)+\left(1-V E_{S}\right) \lambda(a)\left(\sum_{k=1}^{n} V_{k}(a)\right)-(\delta+\mu+\xi(a)) E^{V}(a) \\
& \frac{d I_{M}^{V}(a)}{d t}=\xi(a-1) I_{M}^{V}(a-1)+f_{M}(a) \delta E^{V}(a)-\left(\eta_{M}+\mu+\xi(a)\right) I_{M}^{V}(a) \\
& \frac{d I_{S}^{V}(a)}{d t}=\xi(a-1) I_{S}^{V}(a-1)+f_{S}(a) \delta E^{V}(a)-\left(\eta_{D S}+\mu+\xi(a)\right) I_{S}^{V}(a) \\
& \frac{d I_{C}^{V}(a)}{d t}=\xi(a-1) I_{C}^{V}(a-1)+f_{C}(a) \delta E^{V}(a)-\left(\eta_{D C}+\mu+\xi(a)\right) I_{C}^{V}(a) \\
& \frac{d D_{S}^{V}(a)}{d t}=\xi(a-1) D_{S}^{V}(a-1)+\eta_{D S} I_{S}^{V}(a)-\left(\eta_{S}+\mu+\xi(a)\right) D_{S}^{V}(a)
\end{aligned}
$$




$$
\begin{aligned}
& \frac{d D_{C}^{V}(a)}{d t}=\xi(a-1) D_{C}^{V}(a-1)+\eta_{D C} I_{C}^{V}(a)-\left(\eta_{C}+\mu+\xi(a)+\alpha(a)\right) D_{C}^{V}(a) \\
& \frac{d R_{1}^{V}(a)}{d t}=\xi(a-1) R_{1}^{V}(a-1)+\gamma(a) R_{1}(a)+\eta_{M} I_{M}^{V}(a)+\eta_{S} D_{S}^{V}(a)+\eta_{C} D_{C}^{V}(a)-(\mu+\xi(a)+n \omega(a)) R_{1}^{V}(a)
\end{aligned}
$$

For $\mathrm{k}=2, . . \mathrm{n}$

$$
\frac{d R_{k}^{V}(a)}{d t}=\xi(a-1) R_{k}^{V}(a-1)+\gamma(a) R_{k}(a)+n \omega(a) R_{k-1}^{V}(a)-(\mu+\xi(a)+n \omega(a)) R_{k}^{V}(a)
$$

Where $n$ stands for the order of the gamma distribution ( $\Gamma$-distribution) describing waning of natural or vaccine immunity.

The definitions of population variables and symbols used in the equations are in Table S1.

Table S1. Definitions of population variables and symbols used in the model.

\begin{tabular}{ll}
\hline Symbol & Definition \\
\hline Transmission dynamics parameters \\
\hline$S(a)$ & Unvaccinated susceptible population \\
\hline$E(a)$ & Unvaccinated latently infected population \\
\hline$I_{M}(a)$ & Unvaccinated population with asymptomatic or mild infection \\
\hline$I_{S}(a)$ & Unvaccinated population with severe infection \\
\hline$I_{C}(a)$ & Unvaccinated population with critical infection \\
\hline$D_{S}(a)$ & Unvaccinated population with severe disease \\
\hline$D_{C}(a)$ & Unvaccinated population with critical disease \\
\hline$R_{i}(a)$ & $\begin{array}{l}i^{\text {th }} \text { compartment to generate the gamma distribution for the waning of natural immunity } \\
\text { among the unvaccinated recovered population }\end{array}$ \\
\hline$V_{i}(a)$ & $\begin{array}{l}i^{\text {th }} \text { compartment to generate the gamma distribution for the waning of vaccine immunity } \\
\text { among the vaccinated susceptible population }\end{array}$ \\
\hline$E^{V}(a)$ & Vaccinated latently infected population \\
\hline$I_{M}^{V}(a)$ & Vaccinated population with asymptomatic or mild infection \\
\hline$I_{S}^{V}(a)$ & Vaccinated population with severe infection \\
\hline$I_{C}^{V}(a)$ & Vaccinated population with critical infection \\
\hline$D_{S}^{V}(a)$ & Vaccinated population with severe disease \\
\hline$D_{C}^{V}(a)$ & Vaccinated population with critical disease \\
\hline$R_{i}^{V}(a)$ & $\begin{array}{l}i^{\text {th }} \text { compartment to generate the gamma distribution for the waning of natural immunity } \\
\text { among the vaccinated recovered population }\end{array}$ \\
\hline$N$ & Total population size \\
\hline$n_{a g e}$ & Number of age groups \\
\hline$n$ & $\begin{array}{l}\text { Order of the gamma distribution ( } \Gamma \text {-distribution) describing waning of natural or vaccine } \\
\text { immunity }\end{array}$ \\
\hline$\xi(a)$ & Transition rate from one age group to the next age group \\
\hline $1 / \delta$ & Duration of latent infection \\
\hline & \\
\hline
\end{tabular}




\begin{tabular}{ll}
\hline $1 / \eta_{M}$ & Duration of asymptomatic or mild infection \\
\hline $1 / \eta_{D S}$ & Duration of severe infection infectiousness before isolation and/or hospitalization \\
\hline $1 / \eta_{S}$ & Duration of severe disease following onset of severe disease \\
\hline $1 / \eta_{D C}$ & Duration of critical infection infectiousness before isolation and/or hospitalization \\
\hline $1 / \eta_{C}$ & Duration of critical disease following onset of critical disease \\
\hline $1 / \eta_{R}$ & Duration of natural immunity \\
\hline $1 / \mu$ & Natural death rate \\
\hline$\alpha(a)$ & Mortality rate in each age group \\
\hline$f_{M}(a)$ & Proportion of infections that will progress to be mild or asymptomatic infections \\
\hline$f_{S}(a)$ & Proportion of infections that will progress to be severe infections \\
\hline$f_{C}(a)$ & Proportion of infections that will progress to be critical infections \\
\hline Key vaccine product characteristics \\
\hline$V E_{s}$ & Vaccine efficacy in reducing susceptibility \\
\hline$V E_{P}$ & Vaccine efficacy in reducing severe and critical disease \\
\hline $1 / \omega$ & Duration of vaccine protection \\
\hline
\end{tabular}

The force of infection (hazard rate of infection) experienced by the unvaccinated susceptible populations $S(a)$ is given by

$$
\lambda(a)=\beta \sum_{a^{\prime}=1}^{n_{a g e}} \mathscr{H}_{a, a^{\prime}} \frac{I_{M}\left(a^{\prime}\right)+I_{S}\left(a^{\prime}\right)+I_{C}\left(a^{\prime}\right)+I_{M}^{V}\left(a^{\prime}\right)+I_{S}^{V}\left(a^{\prime}\right)+I_{C}^{V}\left(a^{\prime}\right)}{\left[\begin{array}{l}
S\left(a^{\prime}\right)+E\left(a^{\prime}\right)+I_{M}\left(a^{\prime}\right)+I_{S}\left(a^{\prime}\right)+I_{C}\left(a^{\prime}\right)+D_{S}\left(a^{\prime}\right)+D_{C}\left(a^{\prime}\right)+\sum_{i=1}^{n} R_{i}\left(a^{\prime}\right)+ \\
\sum_{i=1}^{n} V_{i}\left(a^{\prime}\right)+E^{V}\left(a^{\prime}\right)+I_{M}^{V}\left(a^{\prime}\right)+I_{S}^{V}\left(a^{\prime}\right)+I_{C}^{V}\left(a^{\prime}\right)+D_{S}^{V}\left(a^{\prime}\right)+D_{C}^{V}\left(a^{\prime}\right)+\sum_{i=1}^{n} R_{i}^{V}\left(a^{\prime}\right)
\end{array}\right]},
$$

while that experienced by the vaccinated susceptible populations $V(a)$ is given by

$$
\lambda^{V}(a)=\left(1-V E_{S}\right) \lambda(a)
$$

where $\beta$ is the overall infectious contact rate. The mixing among the different age groups is dictated by the mixing matrix $\mathscr{H}_{a, a^{\prime}}$. This matrix provides the probability that an individual in the $a$ age group will mix with an individual in the $a^{\prime}$ age group (regardless of vaccination status).

The mixing matrix is given by 


$$
\mathscr{H}_{a, a^{\prime}}=e_{A g e} \delta_{a, a^{\prime}}+\left(1-e_{\text {Age }}\right) \frac{\left[\begin{array}{l}
S\left(a^{\prime}\right)+E\left(a^{\prime}\right)+I_{M}\left(a^{\prime}\right)+I_{S}\left(a^{\prime}\right)+I_{C}\left(a^{\prime}\right)+D_{S}\left(a^{\prime}\right)+D_{C}\left(a^{\prime}\right)+\sum_{i=1}^{n} R_{i}^{V}\left(a^{\prime}\right)+ \\
\left.\sum_{i=1}^{n} V_{i}\left(a^{\prime}\right)+E^{V}\left(a^{\prime}\right)+I_{M}^{V}\left(a^{\prime}\right)+I_{S}^{V}\left(a^{\prime}\right)+I_{C}^{V}\left(a^{\prime}\right)+D_{S}^{V}\left(a^{\prime}\right)+D_{C}^{V}\left(a^{\prime}\right)+\sum_{i=1}^{n} R_{i}^{V}\left(a^{\prime}\right)\right]
\end{array}\right.}{\sum_{a=1}^{n_{a g e}}\left[\begin{array}{l}
S(a)+E(a)+I_{M}(a)+I_{S}(a)+I_{C}(a)+D_{S}(a)+D_{C}(a)+\sum_{i=1}^{n} R_{i}^{V}(a)+ \\
\left.\sum_{i=1}^{n} V_{i}(a)+E^{V}(a)+I_{M}^{V}(a)+I_{S}^{V}(a)+I_{C}^{V}(a)+D_{S}^{V}(a)+D_{C}^{V}(a)+\sum_{i=1}^{n} R_{i}^{V}(a)\right]
\end{array}\right]}
$$

Here, $\delta_{a, a^{\prime}}$ is the identity matrix. $e_{\text {Age }} \in[0,1]$ measures the degree of assortativeness in the mixing.

At the extreme $e_{\text {Age }}=0$, the mixing is fully proportional. Meanwhile, at the other extreme,

$e_{\text {Age }}=1$, the mixing is fully assortative, that is individuals mix only with members in their own age group.

\section{B. Model adjustment for a vaccine that reduces only severe and critical disease}

The above model was adjusted to accommodate for a vaccine that has no effect on infection, but that reduces both severe and critical disease with an efficacy $V E_{P}$. A schematic diagram of the adjusted model is provided in Figure S2. 
Figure S2. Schematic diagram describing the SARS-CoV-2 transmission dynamics model in presence of a vaccine that reduces severe and critical disease, but does not prevent infection.

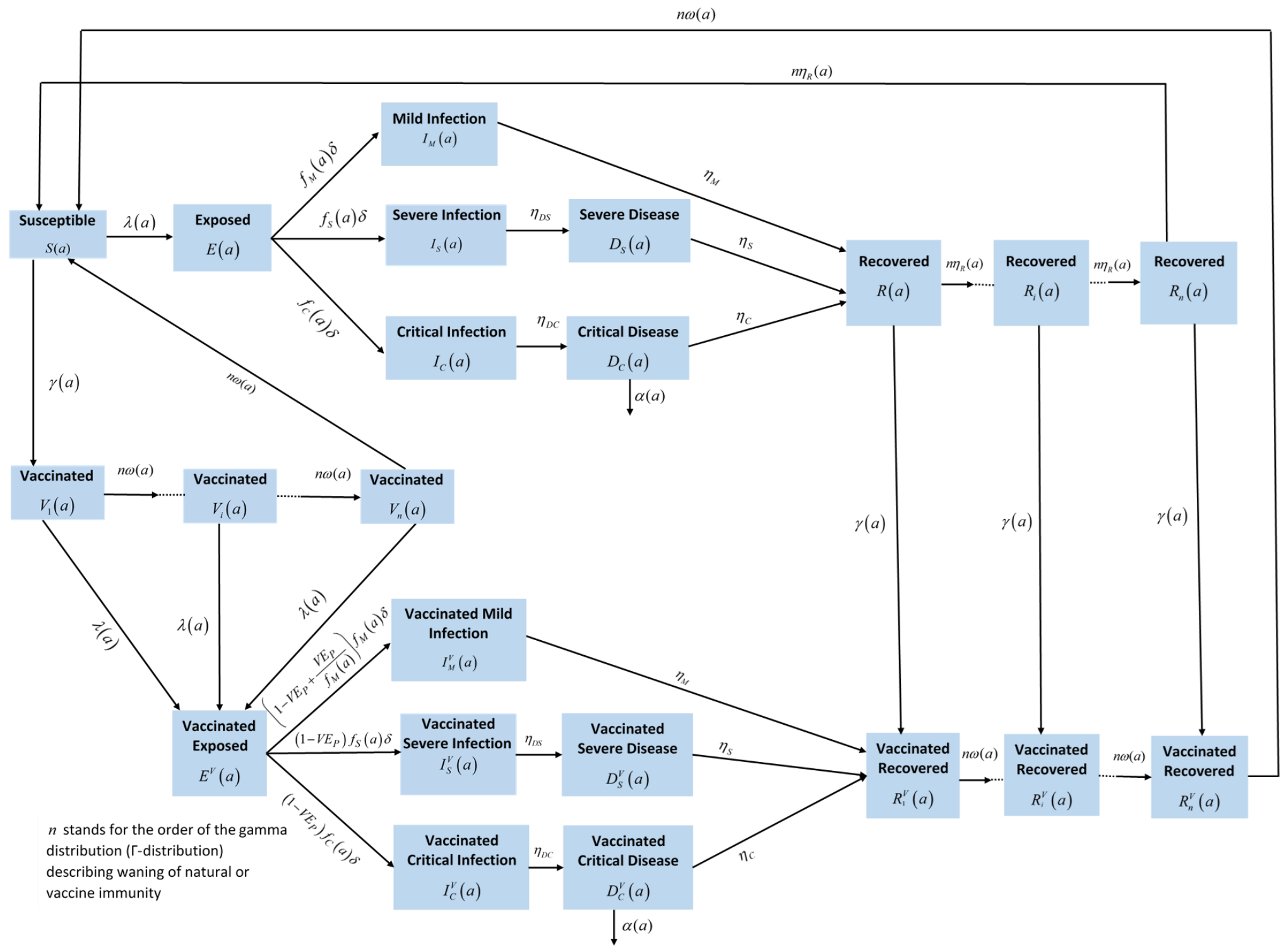


medRxiv preprint doi: https://doi.org/10.1101/2021.01.07.21249380; this version posted January 8, 2021. The copyright holder for this preprint (which was not certified by peer review) is the author/funder, who has granted medRxiv a license to display the preprint in perpetuity. All rights reserved. No reuse allowed without permission.

Figure S3. Time course of waning natural infection and vaccine immunity. Waning of natural infection and vaccine immunity was parametrized using a gamma distribution with order $n=15$. That is, most people lose their immunity after about one year and only a small minority lose it much sooner or much later than one year.

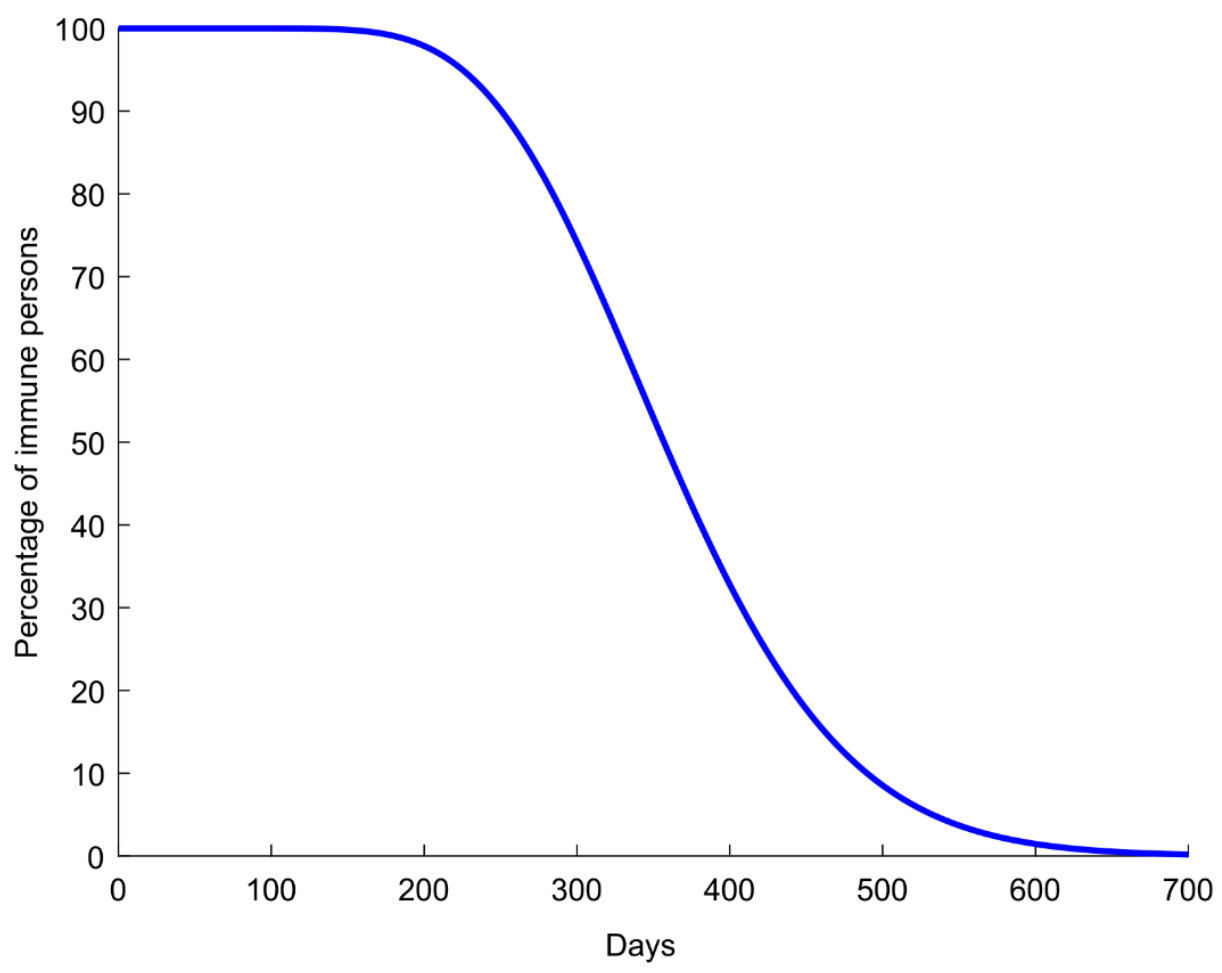




\section{Parameter values}

The input parameters of the model were chosen based on current empirical data for SARS-CoV2 natural history and epidemiology. The parameter values are listed in Table S2.

Table S2. Model assumptions in terms of parameter values

\begin{tabular}{|c|c|c|c|}
\hline Parameter & Symbol & Value & Justification \\
\hline $\begin{array}{l}\text { Duration of latent } \\
\text { infection }\end{array}$ & $1 / \delta$ & 3.69 days & $\begin{array}{l}\text { Based on existing estimate [6] and based } \\
\text { on a median incubation period of } 5.1 \\
\text { days [7] adjusted by observed viral load } \\
\text { among infected persons [8] and reported } \\
\text { transmission before onset of symptoms } \\
\text { [9] }\end{array}$ \\
\hline $\begin{array}{l}\text { Duration of } \\
\text { infectiousness }\end{array}$ & $\begin{array}{l}1 / \eta_{M} \\
1 / \eta_{D S} \\
1 / \eta_{D C}\end{array}$ & 3.48 days & $\begin{array}{l}\text { Based on existing estimate }[6] \text { and based } \\
\text { on observed time to recovery among } \\
\text { persons with mild infection }[6,10] \text { and } \\
\text { observed viral load in infected persons } \\
{[8,9,11]}\end{array}$ \\
\hline $\begin{array}{l}\text { Duration of severe } \\
\text { disease following onset } \\
\text { of severe disease }\end{array}$ & $1 / \eta_{S}$ & 28 days & $\begin{array}{l}\text { Observed duration from onset of severe } \\
\text { disease to recovery [10] }\end{array}$ \\
\hline $\begin{array}{l}\text { Duration of } \\
\text { hospitalization for } \\
\text { critical infection }\end{array}$ & $1 / \eta_{C}$ & 42 days & $\begin{array}{l}\text { Observed duration from onset of critical } \\
\text { disease to recovery [10] }\end{array}$ \\
\hline $\begin{array}{l}\text { Life expectancy in US } \\
\text { Life expectancy in China }\end{array}$ & $\begin{array}{l}1 / \mu \\
1 / \mu\end{array}$ & $\begin{array}{l}79.10 \text { years } \\
76.47 \text { years }\end{array}$ & $\begin{array}{l}\text { United Nations World Population } \\
\text { Prospects database [12] }\end{array}$ \\
\hline $\begin{array}{l}\text { Proportion of infections } \\
\text { that will progress to be } \\
\text { mild or asymptomatic } \\
\text { infections }\end{array}$ & $f_{M}(a)$ & $\begin{array}{c}\text { Determined from } \\
f_{M}(a)+f_{S}(a)+f_{C}(a)=1\end{array}$ & $\begin{array}{l}\text { Observed proportion of infections that } \\
\text { eventually develop mild or } \\
\text { asymptomatic in France }[10,13,14]\end{array}$ \\
\hline $\begin{array}{l}\text { Proportion of infections } \\
\text { that will progress to be } \\
\text { infections that require } \\
\text { hospitalization in acute } \\
\text { care beds }\end{array}$ & $f_{S}(a)$ & & $\begin{array}{l}\text { The distribution and age dependence of } \\
\text { asymptomatic/mild, severe, or critical } \\
\text { infections was based on the modeled } \\
\text { SARS-CoV-2 epidemic in France [15] }\end{array}$ \\
\hline Age 0-19 years & $R R S 1 \times f_{S}$ & $R R S 1=0.1$ & $\begin{array}{l}\text { Model-estimated relative risk of severe } \\
\text { infection based on the SARS-CoV-2 } \\
\text { epidemic in France [15] }\end{array}$ \\
\hline Age $20-29$ years & $R R S 2 \times f_{S}$ & $R R S 2=0.5$ & $\begin{array}{l}\text { Model-estimated relative risk of severe } \\
\text { infection based on the SARS-CoV-2 } \\
\text { epidemic in France [15] }\end{array}$ \\
\hline Age $30-39$ years & $f_{S}$ & $\begin{array}{l}\text { Reference category } \\
\qquad\left(f_{S}=0.01\right)\end{array}$ & $\begin{array}{l}\text { Model-estimated based on fitting the } \\
\text { SARS-CoV-2 epidemic in France [15] }\end{array}$ \\
\hline Age $40-49$ years & $R R S 3 \times f_{S}$ & $R R S 3=1.2$ & $\begin{array}{l}\text { Model-estimated relative risk of severe } \\
\text { infection based on the SARS-CoV-2 } \\
\text { epidemic in France [15] }\end{array}$ \\
\hline Age $50-59$ years & $R R S 4 \times f_{S}$ & $R R S 4=2.3$ & $\begin{array}{l}\text { Model-estimated relative risk of severe } \\
\text { infection based on the SARS-CoV-2 } \\
\text { epidemic in France [15] }\end{array}$ \\
\hline
\end{tabular}




\begin{tabular}{|c|c|c|c|}
\hline Age $60-69$ years & $R R S 5 \times f_{S}$ & $R R S 5=4.5$ & $\begin{array}{l}\text { Model-estimated relative risk of severe } \\
\text { infection based on the SARS-CoV-2 } \\
\text { epidemic in France [15] }\end{array}$ \\
\hline Age $70-79$ years & $R R S 6 \times f_{S}$ & $R R S 6=7.8$ & $\begin{array}{l}\text { Model-estimated relative risk of severe } \\
\text { infection based on the SARS-CoV-2 } \\
\text { epidemic in France [15] }\end{array}$ \\
\hline Age $80+$ years & $R R S 7 \times f_{S}$ & $R R S 7=27.6$ & $\begin{array}{l}\text { Model-estimated relative risk of severe } \\
\text { infection based on the SARS-CoV-2 } \\
\text { epidemic in France [15] }\end{array}$ \\
\hline $\begin{array}{l}\text { Proportion of infections } \\
\text { that will progress to be } \\
\text { critical infections }\end{array}$ & $f_{C}(a)$ & & $\begin{array}{l}\text { The distribution and age dependence of } \\
\text { asymptomatic/mild, severe, or critical } \\
\text { infections was based on the modeled } \\
\text { SARS-CoV-2 epidemic in France [15] }\end{array}$ \\
\hline Age 0-19 years & $R R C 1 \times f_{C}$ & $R R C 1=0.21$ & $\begin{array}{l}\text { Model-estimated relative risk of critical } \\
\text { infection based on the SARS-CoV-2 } \\
\text { epidemic in France [15] }\end{array}$ \\
\hline Age $20-29$ years & $R R C 2 \times f_{C}$ & $R R C 2=0.33$ & $\begin{array}{l}\text { Model-estimated relative risk of critical } \\
\text { infection based on the SARS-CoV-2 } \\
\text { epidemic in France [15] }\end{array}$ \\
\hline Age $30-39$ years & $f_{C}$ & $\begin{array}{l}\text { Reference category } \\
\quad f_{C}=0.0002\end{array}$ & $\begin{array}{l}\text { Model-estimated based on fitting the } \\
\text { SARS-CoV-2 epidemic in France [15] }\end{array}$ \\
\hline Age $40-49$ years & $R R C 3 \times f_{C}$ & $R R C 3=1.83$ & $\begin{array}{l}\text { Model-estimated relative risk of critical } \\
\text { infection based on the SARS-CoV-2 } \\
\text { epidemic in France [15] }\end{array}$ \\
\hline Age $50-59$ years & $R R C 4 \times f_{C}$ & $R R C 4=4.67$ & $\begin{array}{l}\text { Model-estimated relative risk of critical } \\
\text { infection based on the SARS-CoV-2 } \\
\text { epidemic in France [15] }\end{array}$ \\
\hline Age $50-59$ years & $R R C 4 \times f_{C}$ & $R R C 4=4.67$ & $\begin{array}{l}\text { Model-estimated relative risk of critical } \\
\text { infection based on the SARS-CoV-2 } \\
\text { epidemic in France [15] }\end{array}$ \\
\hline Age $60-69$ years & $R R C 5 \times f_{C}$ & $R R C 5=10.58$ & $\begin{array}{l}\text { Model-estimated relative risk of critical } \\
\text { infection based on the SARS-CoV-2 } \\
\text { epidemic in France [15] }\end{array}$ \\
\hline \multirow[t]{2}{*}{ Age $70-79$ years } & $R R C 6 \times f_{C}$ & $R R C 6=13.61$ & $\begin{array}{l}\text { Model-estimated relative risk of critical } \\
\text { infection based on the SARS-CoV-2 } \\
\text { epidemic in France [15] }\end{array}$ \\
\hline & $R R C 7 \times f_{C}$ & $R R C 7=8.67$ & $\begin{array}{l}\text { Model-estimated relative risk of critical } \\
\text { infection based on the SARS-CoV-2 } \\
\text { epidemic in France [15] }\end{array}$ \\
\hline $\begin{array}{l}\text { Disease mortality rate in } \\
\text { each age group }\end{array}$ & $\alpha(a)$ & & $\begin{array}{l}\text { The distribution and age dependence of } \\
\text { COVID-19 mortality was based on the } \\
\text { modeled SARS-CoV-2 epidemic in } \\
\text { France [15] }\end{array}$ \\
\hline Age 0-19 years & $R R D 1 \times \alpha$ & $R R D 1=0.10$ & $\begin{array}{l}\text { Model-estimated relative risk of death } \\
\text { based on the SARS-CoV-2 epidemic in } \\
\text { France [15] }\end{array}$ \\
\hline Age $20-29$ years & $R R D 2 \times \alpha$ & $R R D 2=0.40$ & $\begin{array}{l}\text { Model-estimated relative risk of death } \\
\text { based on the SARS-CoV-2 epidemic in } \\
\text { France [15] }\end{array}$ \\
\hline Age $30-39$ years & $\alpha$ & $\begin{array}{l}\text { Reference category } \\
\qquad(\alpha=0.0006)\end{array}$ & $\begin{array}{l}\text { Model-estimated based on fitting the } \\
\text { SARS-CoV-2 epidemic in France [15] }\end{array}$ \\
\hline Age $40-49$ years & $R R D 3 \times \alpha$ & $R R D 3=3.00$ & $\begin{array}{l}\text { Model-estimated relative risk of death } \\
\text { based on the SARS-CoV-2 epidemic in } \\
\text { France [15] }\end{array}$ \\
\hline
\end{tabular}


medRxiv preprint doi: https://doi.org/10.1101/2021.01.07.21249380; this version posted January 8, 2021. The copyright holder for this preprint (which was not certified by peer review) is the author/funder, who has granted medRxiv a license to display the preprint in perpetuity.

All rights reserved. No reuse allowed without permission.

\begin{tabular}{|c|c|c|c|}
\hline Age $50-59$ years & $R R D 4 \times \alpha$ & $R R D 4=10.00$ & $\begin{array}{l}\text { Model-estimated relative risk of death } \\
\text { based on the SARS-CoV-2 epidemic in } \\
\text { France [15] }\end{array}$ \\
\hline Age $60-69$ years & $R R D 5 \times \alpha$ & $R R D 5=45.00$ & $\begin{array}{l}\text { Model-estimated relative risk of death } \\
\text { based on the SARS-CoV-2 epidemic in } \\
\text { France [15] }\end{array}$ \\
\hline \multirow[t]{2}{*}{ Age $70-79$ years } & $R R D 6 \times \alpha$ & $R R D 6=120.00$ & $\begin{array}{l}\text { Model-estimated relative risk of death } \\
\text { based on the SARS-CoV-2 epidemic in } \\
\text { France [15] }\end{array}$ \\
\hline & $R R D 7 \times \alpha$ & $R R D 7=505.00$ & $\begin{array}{l}\text { Model-estimated relative risk of death } \\
\text { based on the SARS-CoV-2 epidemic in } \\
\text { France [15] }\end{array}$ \\
\hline \multirow[t]{2}{*}{$\begin{array}{l}\text { Overall infectious } \\
\text { contact rate }\end{array}$} & $\beta$ & 0.33 contacts per day & $\begin{array}{l}\text { Chosen to yield the desired value of } \\
R_{0}=1.2 \text { in the US }\end{array}$ \\
\hline & & 0.28 contacts per day & $\begin{array}{l}\text { Chosen to yield the desired value of } \\
R_{0}=1.0 \text { in China }\end{array}$ \\
\hline
\end{tabular}


medRxiv preprint doi: https://doi.org/10.1101/2021.01.07.21249380; this version posted January 8, 2021. The copyright holder for this preprint (which was not certified by peer review) is the author/funder, who has granted medRxiv a license to display the preprint in perpetuity.

Figure S4. Impact of SARS-CoV-2 vaccination on numbers of A) new infections, B) new severe disease cases, $C$ ) new critical disease cases, and D) new deaths in the United States.

The vaccine is assumed to have no efficacy against infection, but an efficacy of $95 \%$ against severe and critical disease. It is introduced on January 1, 2021, when the cumulative proportion of the population infected is $20 \%$. Vaccine coverage is scaled up to reach $80 \%$ by December 31 , 2021. The duration of both vaccine protection and natural immunity is one year. This scenario assumes an $R_{0}$ of 1.2 on January 1, 2021, which increases with gradual easing of restrictions to reach 4.0 after six months.

\section{United States}

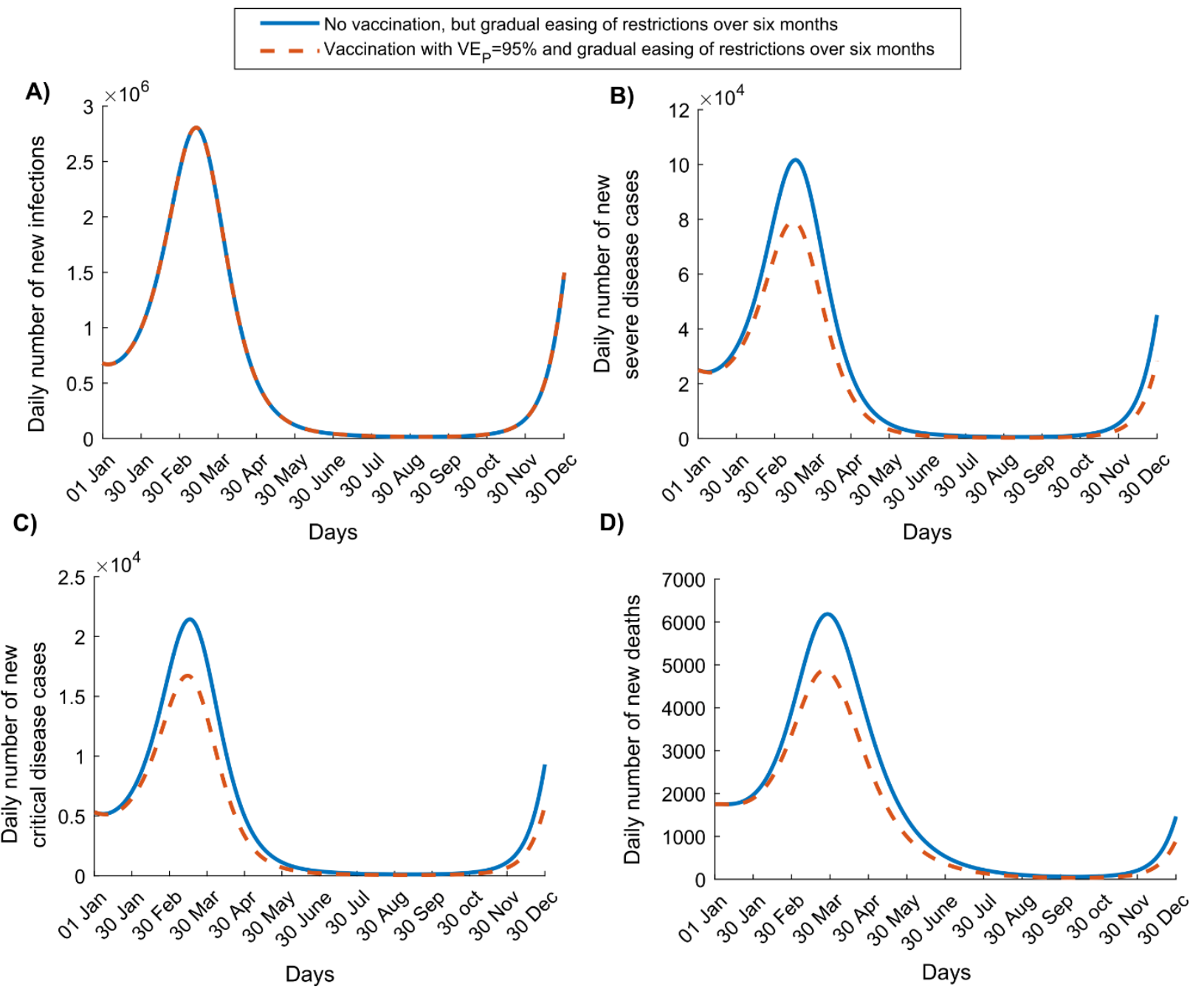


medRxiv preprint doi: https://doi.org/10.1101/2021.01.07.21249380; this version posted January 8, 2021. The copyright holder for this preprint (which was not certified by peer review) is the author/funder, who has granted medRxiv a license to display the preprint in perpetuity.

Figure S5. Impact of SARS-CoV-2 vaccination on numbers of A) new infections, B) new severe disease cases, $C$ ) new critical disease cases, and D) new deaths in China. The vaccine is assumed to have no efficacy against infection, but an efficacy of $95 \%$ against severe and critical disease and is introduced on January 1, 2021. Vaccine coverage is scaled up to reach $80 \%$ by December 31, 2021. The duration of both vaccine protection and natural immunity is one year. This scenario assumes an $R_{0}$ of 1.0 on January 1, 2021, which increases with the gradual easing of restrictions to reach 4.0 after six months.

\section{China}

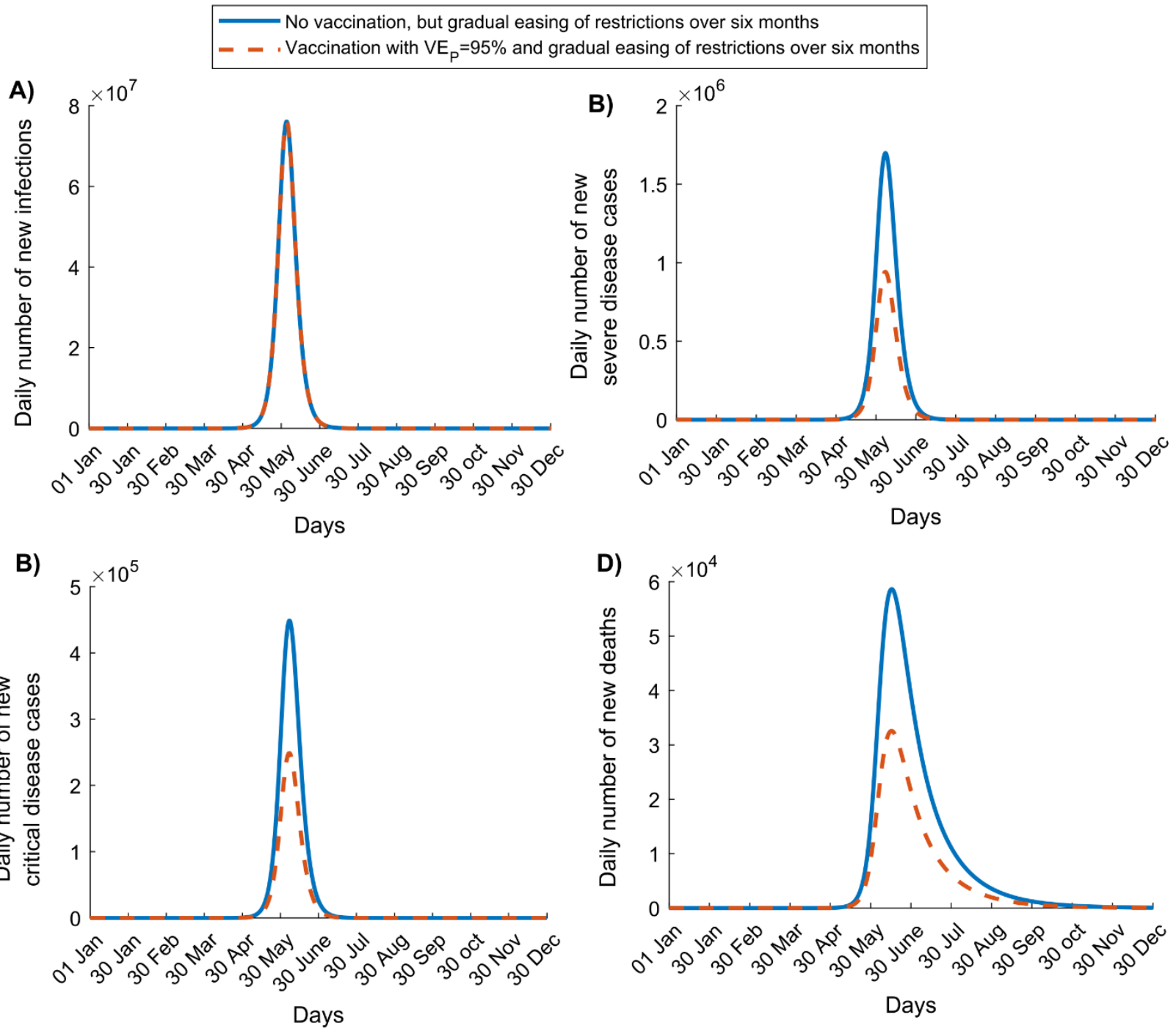


medRxiv preprint doi: https://doi.org/10.1101/2021.01.07.21249380; this version posted January 8, 2021. The copyright holder for this preprint (which was not certified by peer review) is the author/funder, who has granted medRxiv a license to display the preprint in perpetuity.

All rights reserved. No reuse allowed without permission.

Figure S6. Impact of vaccine scale-up duration and vaccine coverage on numbers of averted severe and critical disease cases for a vaccine that protects only against disease. Cumulative numbers of averted severe and critical disease cases in A) the United States and C) China at different vaccination scale-up intervals to reach $80 \%$ coverage. Cumulative numbers of averted severe and critical disease cases in B) the United States and D) China at varying levels of vaccine coverage. The vaccine is assumed to have no efficacy against infection, but an efficacy of $95 \%$ against severe and critical disease and is introduced on January 1, 2021, when the cumulative proportion of the population infected is $20 \%$ in the United States and $0 \%$ in China. The duration of both vaccine protection and natural immunity is one year. This scenario assumes a gradual easing of restrictions within 6 months.

A)

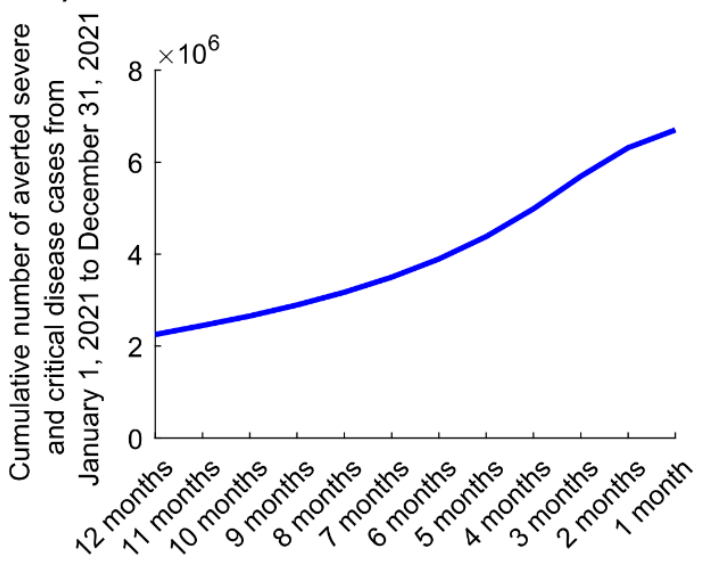

Scale-up duration for the vaccine to reach $80 \%$ coverage

C)

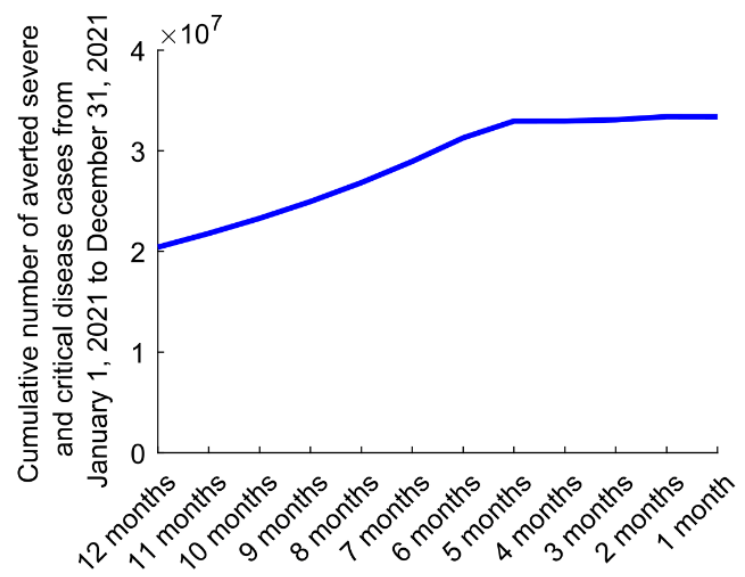

Scale-up duration for the vaccine to reach $80 \%$ coverage
B)

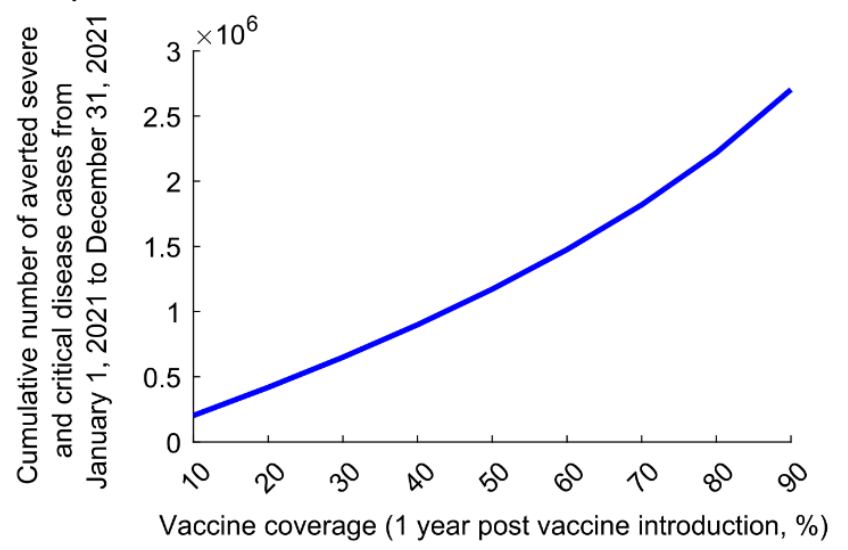

\section{China}

D)

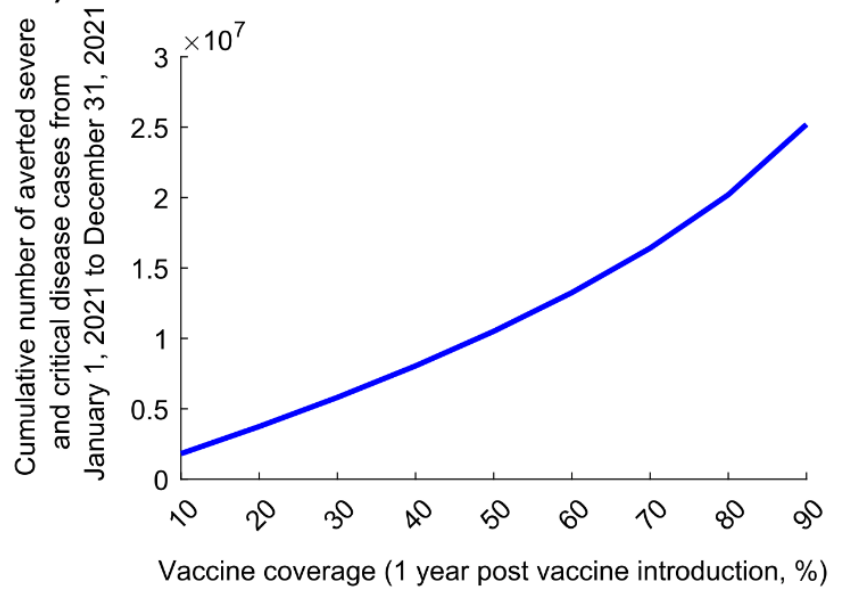


medRxiv preprint doi: https://doi.org/10.1101/2021.01.07.21249380; this version posted January 8, 2021. The copyright holder for this preprint (which was not certified by peer review) is the author/funder, who has granted medRxiv a license to display the preprint in perpetuity.

All rights reserved. No reuse allowed without permission.

Figure S7. Impact of vaccine scale-up duration on the number of vaccinations needed to avert one infection (A), one severe disease case (B), one critical disease case (C), and one death (D) in China. The vaccine is assumed to have an efficacy of 95\% against infection and is introduced on January 1, 2021, when the cumulative proportion of the population infected is $0 \%$. The duration of both vaccine protection and natural immunity is one year. This scenario assumes a gradual easing of restrictions within 6 months.

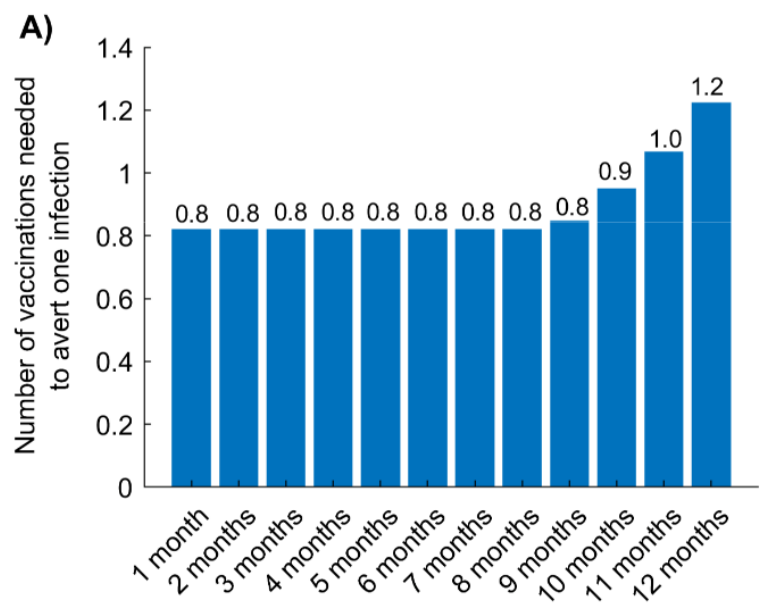

Scale-up duration for the vaccine to reach $80 \%$ coverage

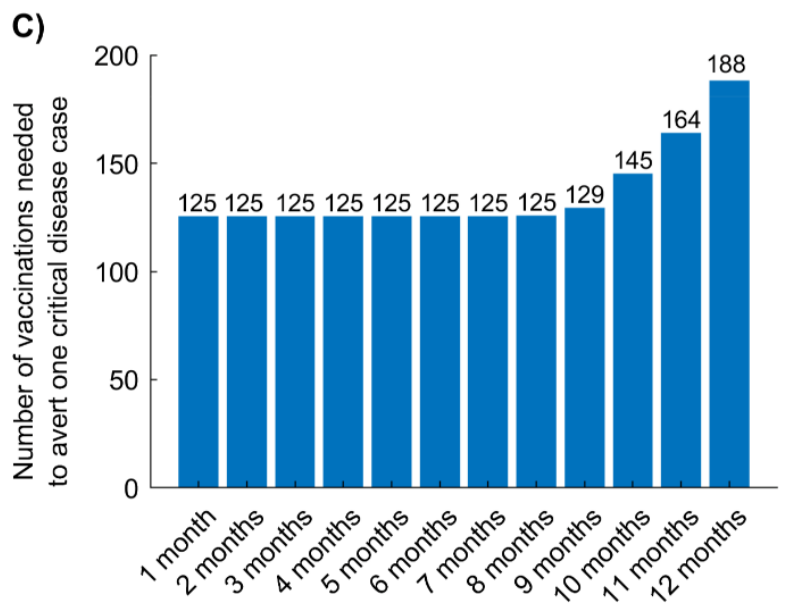

Scale-up duration for the vaccine to reach $80 \%$ coverage

\section{China}

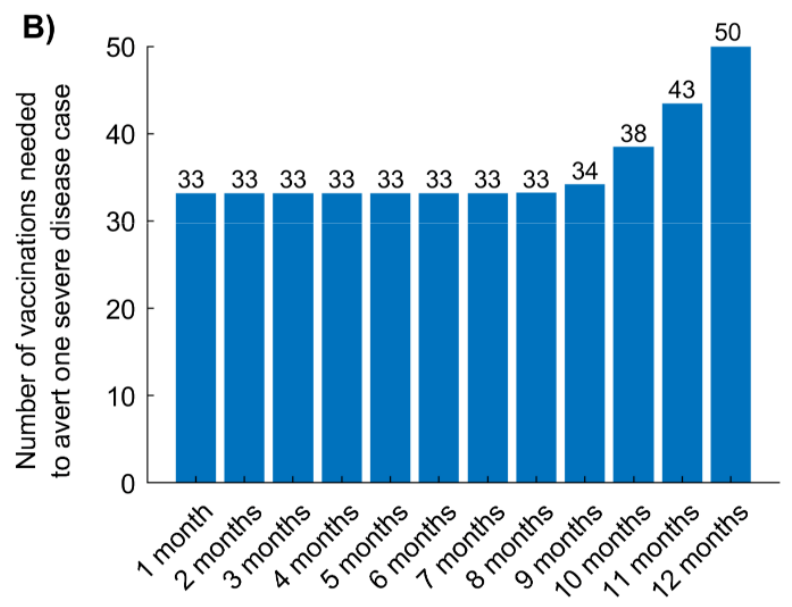

Scale-up duration for the vaccine to reach $80 \%$ coverage

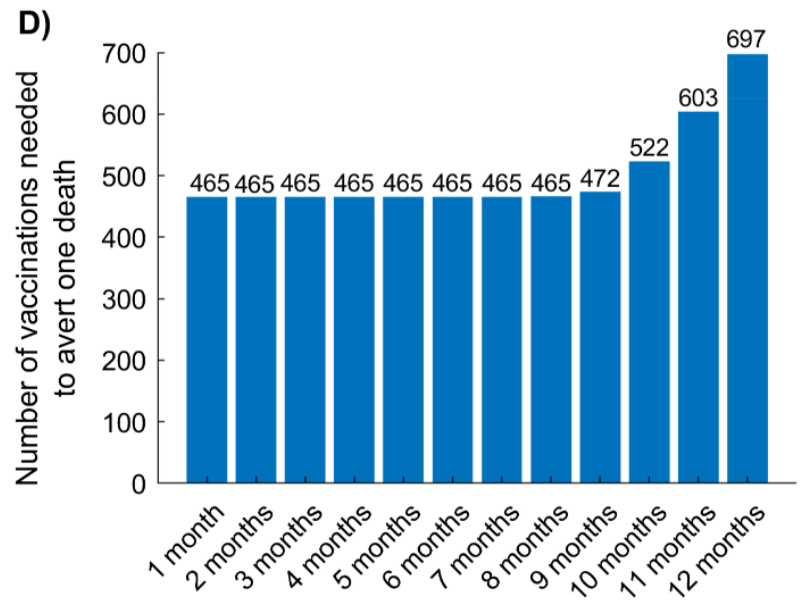

Scale-up duration for the vaccine to reach $80 \%$ coverage 
medRxiv preprint doi: https://doi.org/10.1101/2021.01.07.21249380; this version posted January 8, 2021. The copyright holder for this preprint (which was not certified by peer review) is the author/funder, who has granted medRxiv a license to display the preprint in perpetuity.

All rights reserved. No reuse allowed without permission.

Figure S8. Comparison of the impact of a vaccine acting against infection ( $V E_{S}$ efficacy) versus a vaccine acting only against disease ( $V E_{P}$ efficacy) in China. The number of vaccinations needed to avert one severe disease case (A), one critical disease case (B), and one death $(\mathrm{C})$, for a vaccine with $V E_{S}=95 \%$ versus a vaccine with $V E_{P}=95 \%$. The vaccine is introduced on January 1, 2021, when the cumulative proportion of the population infected is $0 \%$. The duration of both vaccine protection and natural immunity is one year. This scenario assumes a gradual easing of restrictions within 6 months.

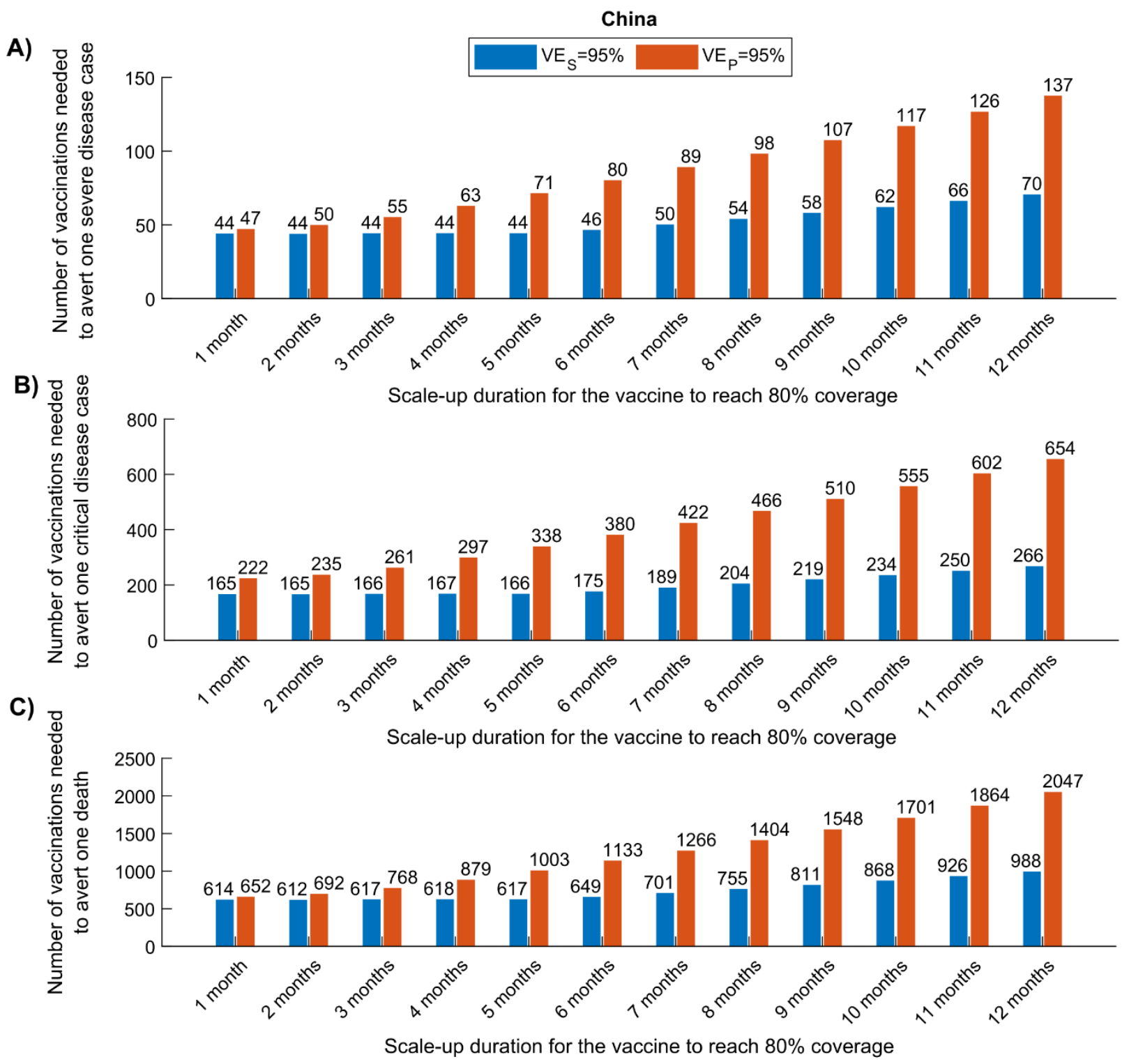


medRxiv preprint doi: https://doi.org/10.1101/2021.01.07.21249380; this version posted January 8, 2021. The copyright holder for this preprint (which was not certified by peer review) is the author/funder, who has granted medRxiv a license to display the preprint in perpetuity.

Figure S9. Impact of the duration of easing social and physical distancing restrictions on the number of averted severe and critical disease cases. The cumulative number of averted severe and critical disease cases in A) the United States and B) China at different durations of easing of restrictions. The vaccine is assumed to have an efficacy of $95 \%$ against infection and is introduced on January 1, 2021, when the cumulative proportion of the population infected is $20 \%$ in the United States and $0 \%$ in China. The duration of both vaccine protection and natural immunity is one year.

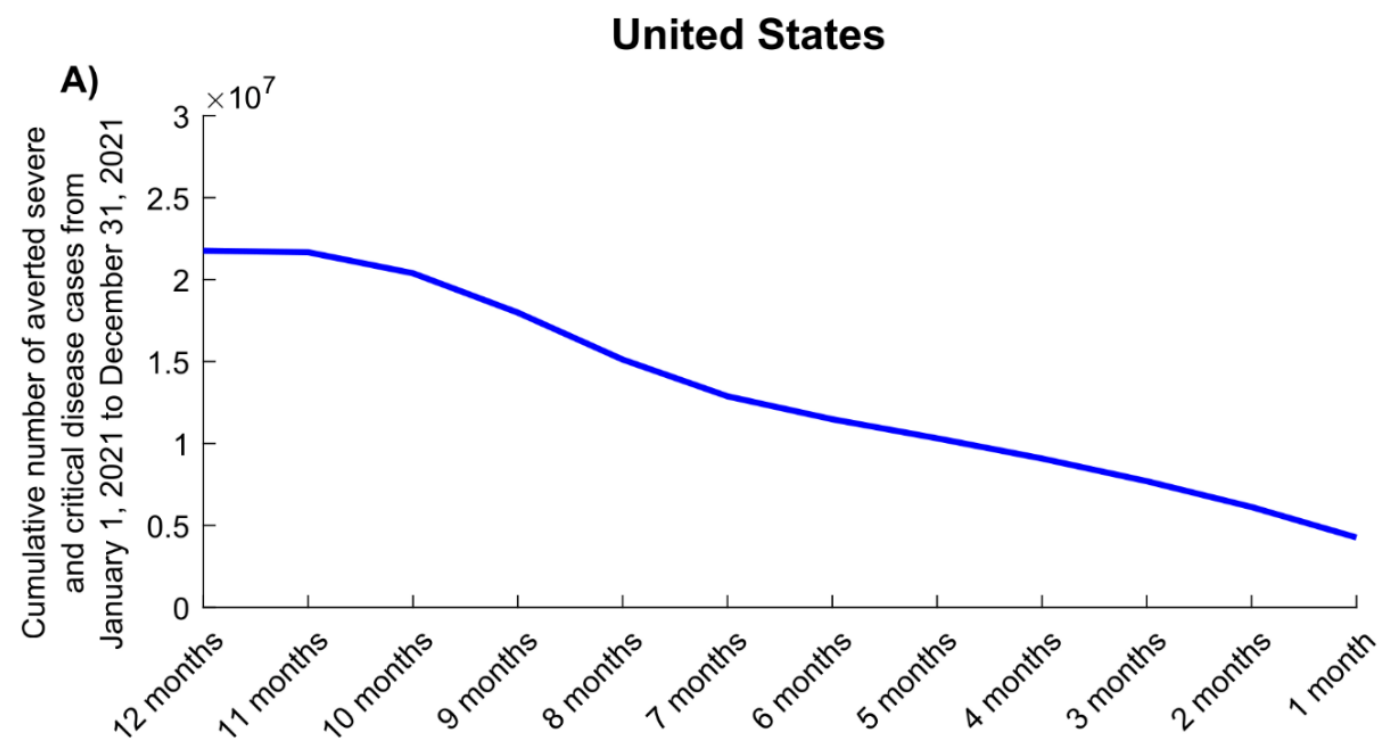

Duration over which the social and physical distancing restrictions are eased

B)

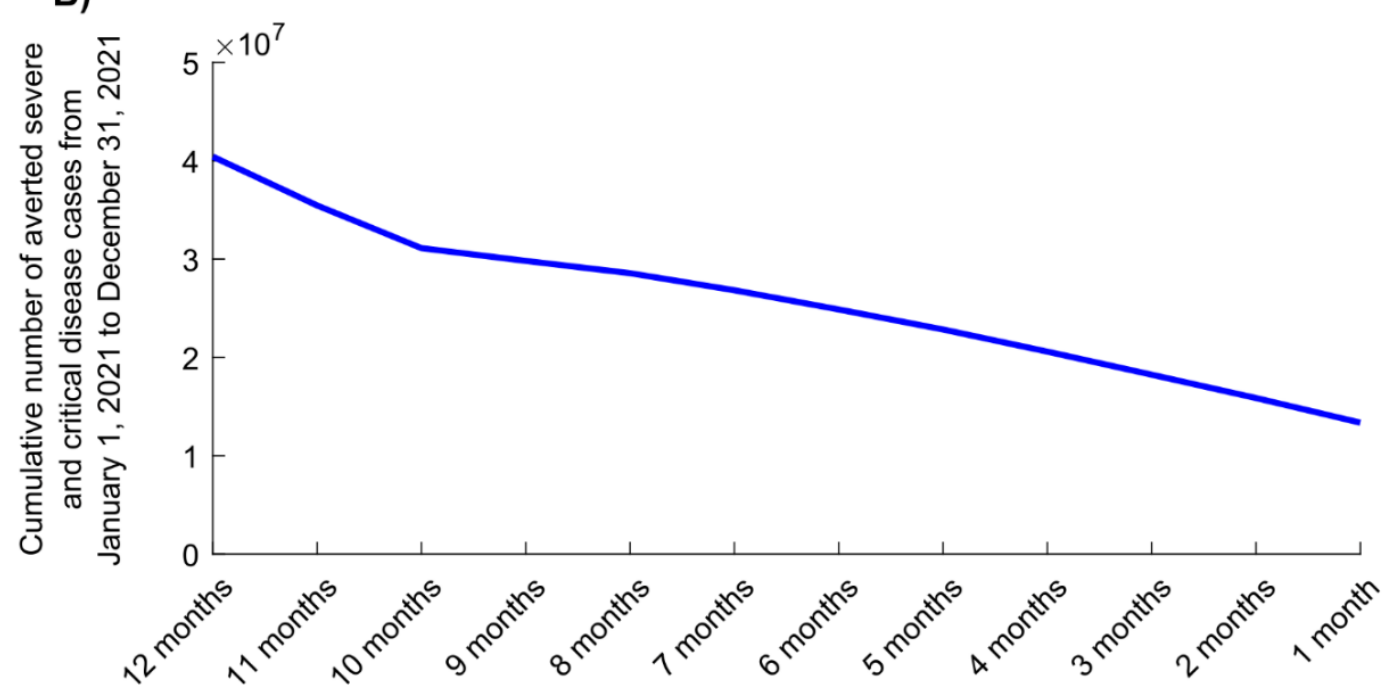

Duration over which the social and physical distancing restrictions are eased 
medRxiv preprint doi: https://doi.org/10.1101/2021.01.07.21249380; this version posted January 8, 2021. The copyright holder for this preprint (which was not certified by peer review) is the author/funder, who has granted medRxiv a license to display the preprint in perpetuity.

All rights reserved. No reuse allowed without permission.

Figure S10. Uncertainty analyses. Numbers of new severe and critical disease cases in the United States assuming A) a vaccine that protects against both infection and disease and B) a vaccine that protects only against disease. Numbers of new severe and critical disease cases in China assuming C) a vaccine that protects against both infection and disease and D) a vaccine that protects only against disease. These scenarios assume gradual easing of restrictions within 6 months. Shaded areas are the results of the 500 uncertainty runs, while the solid line is the mean of those runs.

\section{Mean over 500 uncertainty runs}

\section{United States}

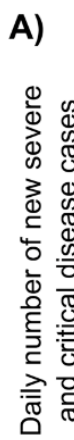

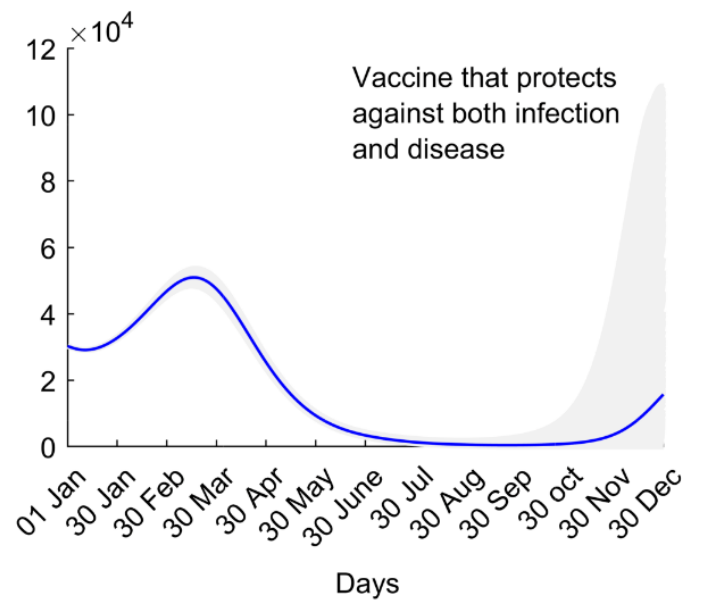

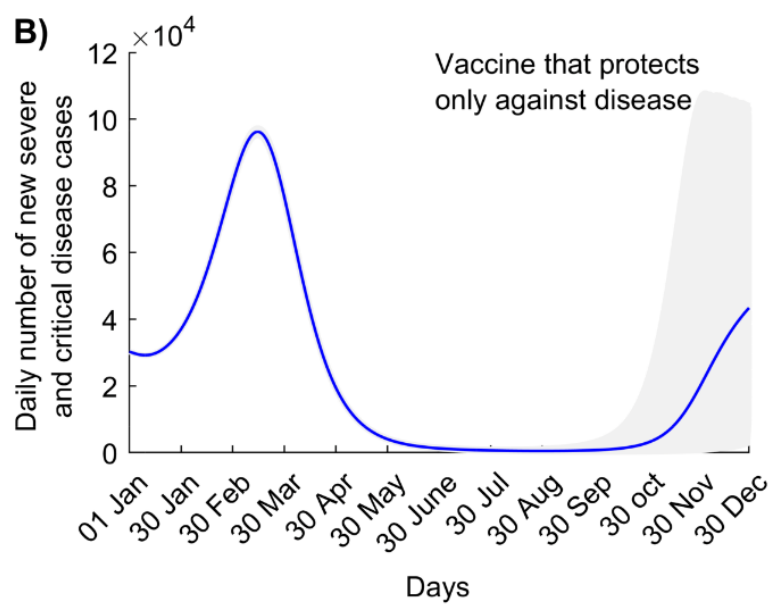

China

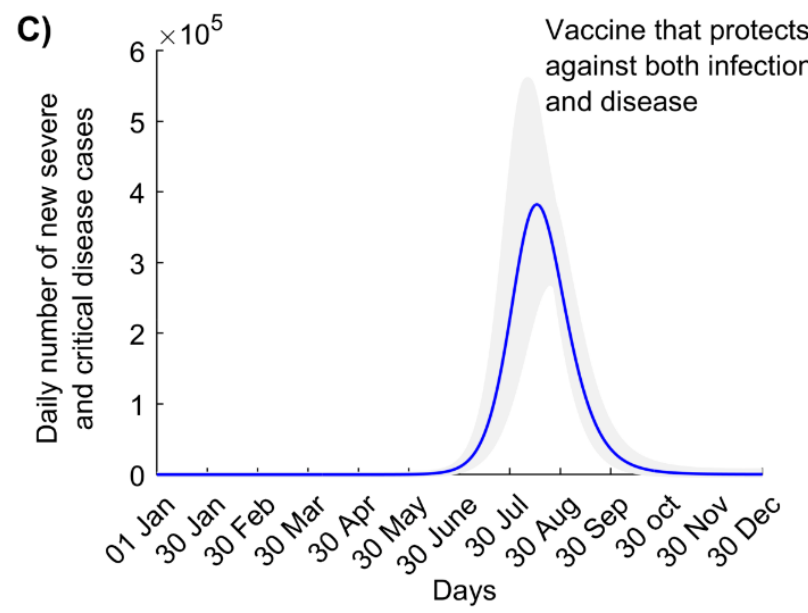

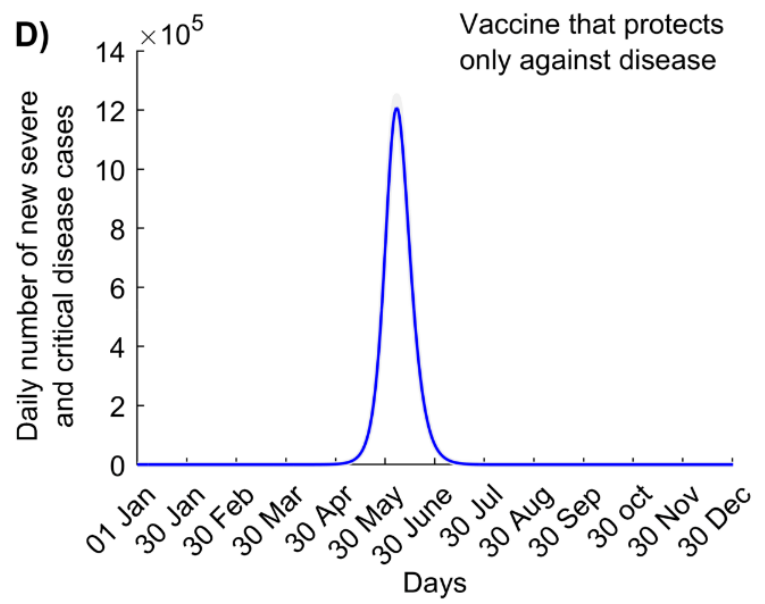


medRxiv preprint doi: https://doi.org/10.1101/2021.01.07.21249380; this version posted January 8, 2021. The copyright holder for this preprint (which was not certified by peer review) is the author/funder, who has granted medRxiv a license to display the preprint in perpetuity. All rights reserved. No reuse allowed without permission.

\section{References}

[1] Makhoul M, Ayoub HH, Chemaitelly H, Seedat S, Mumtaz GR, Al-Omari S, et al. Epidemiological Impact of SARS-CoV-2 Vaccination: Mathematical Modeling Analyses. Vaccines (Basel). 2020;8.

[2] Ayoub HH, Chemaitelly H, Seedat S, Mumtaz GR, Makhoul M, Abu-Raddad LJ. Age could be driving variable SARS-CoV-2 epidemic trajectories worldwide. PLoS One. 2020;15:e0237959.

[3] Ayoub HH, Chemaitelly H, Mumtaz GR, Seedat S, Awad SF, Makhoul M, et al.

Characterizing key attributes of COVID-19 transmission dynamics in China's original outbreak: Model-based estimations. Glob Epidemiol. 2020;2:100042.

[4] Makhoul M, Abou-Hijleh F, Seedat S, Mumtaz GR, Chemaitelly H, Ayoub H, et al. Analyzing inherent biases in SARS-CoV-2 PCR and serological epidemiologic metrics. BMCID.Under review.

[5] Seedat S, Chemaitelly H, Ayoub H, Makhoul M, Mumtaz GR, Kanaani ZA, et al. SARSCoV-2 infection hospitalization, severity, criticality, and fatality rates. medRxiv. 2020:2020.11.29.20240416.

[6] Li R, Pei S, Chen B, Song Y, Zhang T, Yang W, et al. Substantial undocumented infection facilitates the rapid dissemination of novel coronavirus (SARS-CoV2). Science. 2020;368:48993.

[7] Lauer SA, Grantz KH, Bi Q, Jones FK, Zheng Q, Meredith HR, et al. The Incubation Period of Coronavirus Disease 2019 (COVID-19) From Publicly Reported Confirmed Cases: Estimation and Application. Ann Intern Med. 2020;172:577-82.

[8] Zou L, Ruan F, Huang M, Liang L, Huang H, Hong Z, et al. SARS-CoV-2 Viral Load in Upper Respiratory Specimens of Infected Patients. N Engl J Med. 2020;382:1177-9.

[9] Rothe C, Schunk M, Sothmann P, Bretzel G, Froeschl G, Wallrauch C, et al. Transmission of 2019-nCoV Infection from an Asymptomatic Contact in Germany. N Engl J Med. 2020;382:9701.

[10] World Health Organization. Report of the WHO-China Joint Mission on Coronavirus Disease 2019 (COVID-19). Available from :https://www.who.int/docs/defaultsource/coronaviruse/who-china-joint-mission-on-covid-19-final-report.pdf. Accessed on March 10, 2020. 2020.

[11] He X, Lau EHY, Wu P, Deng X, Wang J, Hao X, et al. Temporal dynamics in viral shedding and transmissibility of COVID-19. Nat Med. 2020;26:672-5.

[12] United Nations Department of Economic and Social Affairs Population Dynamics. The 2019 Revision of World Population Prospects. Available from https://population.un.org/wpp/. Accessed on March 1st, 2020. 2020.

[13] Guan WJ, Ni ZY, Hu Y, Liang WH, Ou CQ, He JX, et al. Clinical Characteristics of Coronavirus Disease 2019 in China. N Engl J Med. 2020.

[14] Huang C, Wang Y, Li X, Ren L, Zhao J, Hu Y, et al. Clinical features of patients infected with 2019 novel coronavirus in Wuhan, China. Lancet. 2020;395:497-506.

[15] Salje H, Tran Kiem C, Lefrancq N, Courtejoie N, Bosetti P, Paireau J, et al. Estimating the burden of SARS-CoV-2 in France. Science. 2020:eabc3517. 